\title{
The role of lipid and carbohydrate digestive enzyme inhibitors in the management of obesity: a review of current and emerging therapeutic agents
}

\author{
This article was published in the following Dove Press journal: \\ Diabetes, Metabolic Syndrome and Obesity:Targets and Therapy \\ 8 May 2010
}

Number of times this article has been viewed

\section{Sonia A Tucci \\ Emma J Boyland \\ Jason CG Halford}

Kissileff Laboratory for the Study of Human Ingestive Behaviour, School of Psychology,

University of Liverpool,

Liverpool, UK
Correspondence: Sonia Tucci Kissileff Laboratory for the Study of Human Ingestive Behaviour, School of Psychology, University of Liverpool, Eleanor Rathbone Building, Bedford Street South, Liverpool, L69 7ZA, UK Tel +44 (0) I5I 794 I I 2 I

Fax +44 (0) I5। 7942945

Email sonia.tucci@liv.ac.uk
Abstract: Obesity is a global epidemic associated with significant morbidity and mortality in adults and ill health in children. A proven successful approach in weight management has been the disruption of nutrient digestion, with orlistat having been used to treat obesity for the last 10 years. Although orlistat-induced weight loss remains modest, it produces meaningful reductions in risk factors for obesity-related conditions such as diabetes and cardiovascular disease. Moreover, this lipase inhibitor is free of the serious side effects that have dogged appetite-suppressing drugs. This success had driven investigation into new generation nutraceuticals, supplements and pharmaceutical agents that inhibit the breakdown of complex carbohydrates and fats within the gut. This review focuses on agents purported to inhibit intestinal enzymes responsible for macronutrient digestion. Except for some synthetic products, the majority of agents reviewed are either botanical extracts or bacterial products. Currently, carbohydrate digestion inhibitors are under development to improve glycemic control and these may also induce some weight loss. However, colonic fermentation induced side effects, such as excess gas production, remain an issue for these compounds. The $\alpha$-glucosidase inhibitor acarbose, and the $\alpha$-amylase inhibitor phaseolamine, have been used in humans with some promising results relating to weight loss. Nonetheless, few of these agents have made it into clinical studies and without any clinical proof of concept or proven efficacy it is unlikely any will enter the market soon.

Keywords: lipase, amylase, saccharidases, overweight, orlistat, $\mathrm{Alli}^{\circledR}$, digestion, body weight

\section{Prevalence and impact of obesity}

A positive energy balance resulting from a chronic disparity between the intake of energy and its expenditure leads to weight gain and eventually obesity. Currently, the global tendency to gain weight poses a major menace to world health. Adiposity (overweight and obesity) constitutes a key risk factor for a variety of adulthood chronic disorders such as dyslipidemia, high blood pressure, type II diabetes, cardiovascular disease, osteoarthritis and some forms of cancer. ${ }^{1}$ In the European Region, $2 \%$ to 8\% of health costs could be attributable to obesity. ${ }^{2}$ Obesity can no longer be considered only a problem of developed, 'Westernized', high income countries. On every continent developing countries are experiencing similar increases in the prevalence of overweight and obesity within their population, particularly in urban settings.

Currently, a body mass index (BMI) of $30 \mathrm{~kg} / \mathrm{m}^{2}$ or greater defines adult obesity, and between 25 and $29.9 \mathrm{~kg} / \mathrm{m}^{2}$ is classified as overweight. However, lower cut off points should be used in certain populations at greater risk of obesity related diseases. In 2005 , 
the World Health Organization (WHO) reported that 1.6 billion adults could be categorized as overweight whilst at least 400 million adults were considered obese. ${ }^{3}$ The WHO predicted that over the next ten years global rates of overweight and obesity would double, and by 2015 roughly 2.3 billion adults would be overweight and over 700 million obese. Europe has followed the global trend - since 1980 the prevalence of obesity has tripled, with levels continuing to rise at an alarming rate.

For intervention, the most common and widely advocated approaches remain changes in lifestyle, specifically dieting and exercise. Achieving significant weight loss is a difficult task and although some individuals manage to lose weight in the short term, for most people maintaining a lower body weight in the long term proves remarkably difficult., ${ }^{4,5}$ Drug therapy offers a reasonable option to overcome obesity when given as an adjunct to life style interventions such as dietary counseling, behavioral modifications and structured exercise. ${ }^{6,7}$ Modest weight reduction ( $5 \%$ to $10 \%$ of total body weight) in patients with obesityassociated medical complications produces beneficial health outcomes. A reduction of 5 to $10 \mathrm{~kg}$ of body weight in moderately obese patients reduces blood pressure and cholesterol levels, and improves glycemia along with a reduced risk of undesirable clinical outcomes including myocardial infarction, stroke and cardiovascular-related death ${ }^{8}$ and increases longevity. ${ }^{9}$

The phenomenon of weight gain suggests that the homeostatic mechanisms regulating energy homeostasis are insufficient to cope with our current obesity promoting environment. However, boosting inhibitory homeostatic feedback could re-establish effective homeostatic control of energy balance and even induce weight loss. Consequently, the mechanisms underpinning the regulation of appetite and energy regulation have received particular attention, notably for the development of anti-obesity drugs. ${ }^{10,11}$ These include drugs that reduce appetite and/or enhance satiety or drugs that stimulate energy expenditure thereby restoring energy balance. Although providing a rich source of drug targets for weight control, this approach ignores the possibility that over-consumption associated with obesity results from the stimulatory effect of the food environment rather than any particular biological deficit (such as in post ingestive satiety from the gut or increased adiposity signals from body fat stores). The withdrawal of appetite-suppressing drugs that act on the central nervous system such as fenfluramine, d-fenfluramine, rimonabant and sibutramine (withdrawn in Europe but still available in the US), suggests that targeting energy regulation systems for weight control is not without problems. Even peripheral appetite targets such as gut peptides implicated in the processes of satiation and satiety such as glucagon-like peptide-1 (GLP)-1 and peptide YY (PYY) are difficult to administer and may induce nausea.

Nonetheless, drugs acting in the periphery provide a viable alternative for weight management and other pharmacological approaches to the treatment of obesity have proved successful, specifically drugs that affect the absorption or partitioning of nutrients. ${ }^{12} \mathrm{~A}$ lipase inhibitor is currently the only prescription medicine available in Europe for obesity treatment. This review will focus on drugs that have, as a potential mechanism, the disruption of fat and carbohydrate absorption. Tables 1 and 2 summarize the doses and effects found in vitro and in vivo studies.

\section{Dietary fat digestion and absorption}

Lipids are fundamental components of all living organisms, and they are calorically dense thus representing an important constituent of human nutrition (approximately $40 \%$ of daily energy intake). Dietary fats are absorbed in the intestine and they function as an energy supply, thermal regulators, membrane constituents, energy storage and some play an important role in body function as essential fatty acids and fat-soluble vitamins. ${ }^{13}$ The human intestine is able to completely absorb approximately $95 \%$ of ingested fat. ${ }^{14}$ Given the efficient absorption of dietary fat it is not surprising that long term intake of a high fat diet is readily converted to adipose tissue particularly in those with low levels of physical activity. ${ }^{15}$ In such a scenario it is logical to assume that the modification of fat absorption could be a potential target to treat obesity and prevent further weight gain.

The main fat constituents $(90 \%)$ of a typical Western diet are triacylglycerols or triglycerides (TG). TG consist of a single molecule of glycerol, attached by ester bonds to three fatty acids. TG cannot be absorbed; therefore, intestinal enzymes must hydrolyze the ester bonds on the glycerol backbone in order for the molecule to be absorbed. The products of this hydrolysis are mainly free fatty acids (FFA) and 2- monoglycerides (2-MG) which can be absorbed by the duodenum. In vivo TG hydrolysis is catalyzed by several digestive lipases. There are several human lipases which include the pre-duodenal (lingual and human gastric lipase (HGL)) and the extra-duodenal (pancreatic, hepatic, lipoprotein and endothelial) lipases. ${ }^{16}$

Lingual lipase is secreted by a serous gland at the back of the tongue and initiates fat digestion. ${ }^{17} \mathrm{HGL}$ is secreted by the chief cells of the fundic mucosa of the stomach, this enzyme is active at a broad $\mathrm{pH}$ range (3 to 6) and is stable even at the low $\mathrm{pH}$ present in the stomach. ${ }^{18}$ The acinar cells of the pancreas synthesize and secrete several lipolytic enzymes such as 
Table I Effective in vitro doses and target enzymes of inhibitors

\begin{tabular}{|c|c|c|c|}
\hline Product & Dose & Effect & Ref \\
\hline \multirow[t]{2}{*}{ Cetilistat } & $54.8 \mathrm{nmol} / \mathrm{L}$ & Inhibits rat pancreatic lipase & 46 \\
\hline & $5.95 \mathrm{nmol} / \mathrm{L}$ & Inhibits HPL & \\
\hline Platycodin DI saponin & $0.18-0.03 \mathrm{mM}$ & Inhibits pancreatic lipase & 82 \\
\hline Sabiosaponin prosapogenin Ib & $0.12 \mathrm{mg} / \mathrm{mL}$ & Inhibits pancreatic lipase & 87 \\
\hline Acanthopanax sessiliflorus & 0.36 and $0.75 \mathrm{mg} / \mathrm{mL}$, respectively & Inhibit pancreatic lipase & 53 \\
\hline \multicolumn{4}{|l|}{ sessiloside and chiisanoside } \\
\hline Acanthopanax senticosus & $0.22-0.29 \mathrm{mM}$ & Inhibit pancreatic lipase & 52,61 \\
\hline \multirow[t]{2}{*}{ triterpenoid saponins } & & Inhibits glucose 6-phosphatase and & \\
\hline & & lipogenic enzymes in liver & \\
\hline Panax japonicum & $125-500 \mu \mathrm{g} / \mathrm{mL}$ & Inhibits pancreatic lipase & 76 \\
\hline \multicolumn{4}{|l|}{ chikusetsusaponin } \\
\hline Dioscorea nipponica extract & $5-10 \mathrm{mg} / \mathrm{mL}$ & Inhibits pancreatic lipase & 72 \\
\hline Kochia scoparia alcohol extract and saponins & $0.25 \mathrm{mg} / \mathrm{mL}$ & Inhibit pancreatic lipase & 213 \\
\hline Aesculus turbinata escins & $20-100 \mu M$ & Inhibit pancreatic lipase & 70 \\
\hline \multirow[t]{3}{*}{ Sapindus rarak extract and saponins } & Extract: $\mathrm{IC}_{50}=614 \mu \mathrm{g} / \mathrm{mL}$ & Inhibit pancreatic lipase & 86 \\
\hline & Rarasaponins IIC $\mathrm{IC}_{50}=|3| \mu \mathrm{M}$ & & \\
\hline & and II I $72 \mu \mathrm{M}$ & & \\
\hline Oolong tea saponins & $\mathrm{Km}$ and $\mathrm{Vmax}$ values of & Inhibit pancreatic lipase & 73,74 \\
\hline \multirow[t]{3}{*}{ (theasaponins EI and E2) } & $1.42 \mathrm{mg} / \mathrm{mL}$ and $476.2 \mathrm{nkat} / \mathrm{L}$ & & \\
\hline & respectively. The Ki value of & & \\
\hline & theasaponin is $0.25 \mathrm{mg} / \mathrm{mL}$ & & \\
\hline Chinese tea saponins chakasaponins I, II, and III & $\mathrm{IC}_{50}$ of $0.091 \mathrm{mg} / \mathrm{mL}$ & Inhibit pancreatic lipase & 71 \\
\hline & $\mathrm{IC}_{50}$ values of $0.17-0.53 \mathrm{mM}$ & & \\
\hline Oolong tea catechins & $05-2 \mathrm{~g} / \mathrm{L}$ & Inhibit pancreatic lipase & 73,203 \\
\hline epigallocatechin 3-O-gallate(-) & $0.34 \mu \mathrm{M}$ & Inhibit pancreatic lipase & \\
\hline epigallocatechin-3,5-digallate & $0.09 \mu \mathrm{M}$ & Inhibit pancreatic lipase & \\
\hline \multirow[t]{3}{*}{ Green tea catechins } & $5-30 \mu \mathrm{M}$ & Inhibit adipocytes differentiation & $\mid 87-189,191,192$ \\
\hline & & Inhibit gastric and pancreatic lipase & \\
\hline & & Inhibit $\alpha$-amylase and $\alpha$-glucosidase & \\
\hline \multirow[t]{2}{*}{ Cyclocarya paliurus } & $5 \mu g / m L$ & Inhibits $\alpha$-glucosidase & 180,181 \\
\hline & $9.1 \mu \mathrm{g} / \mathrm{mL}$ & Inhibits pancreatic lipase & \\
\hline Salacia reticulata polyphenol extracts & $\mathrm{IC}_{50}$ of $264 \mathrm{mg} / \mathrm{L}$ & Inhibit pancreatic lipase & 210 \\
\hline salacinol and kotalanol & & Inhibit $\alpha$-glucosidase & \\
\hline \multirow[t]{2}{*}{ Apple polyphenol procyanidin fractions } & $\mathrm{IC}_{50}$ of $5.6 \mu \mathrm{g} / \mathrm{mL}$ & Inhibit pancreatic lipase & 97 \\
\hline & $\mathrm{IC}_{50}$ of $\mathrm{I} .4 \mu \mathrm{g} / \mathrm{mL}$ & & \\
\hline Grape seed extract & I mg/mL $80 \%$ inhibition & Inhibits pancreatic lipase & 101 \\
\hline \multirow[t]{2}{*}{ Nelumbo nucifera extract } & $\mathrm{IC}_{50}$ of $0.46 \mathrm{mg} / \mathrm{mL}$ & Inhibits lipase & 199 \\
\hline & $\mathrm{IC}_{50}$ of $0.82 \mathrm{mg} / \mathrm{mL}$ & Inhibits $\alpha$-amylase & \\
\hline Cassia mimosoides CT-II extract & $0.1-0.71 \mathrm{mg} / \mu \mathrm{mL}$ & $50 \%$ inhibition porcine lipase & 98 \\
\hline Peanut shell extract & $10 \mathrm{mg} / \mathrm{mL}$ & $92 \%$ inhibition of human lipase & 207 \\
\hline \multirow[t]{2}{*}{ Carnosic acid and carnasol } & $\mathrm{IC}_{50}$ of $36 \mu \mathrm{M}$ & Inhibit pancreatic lipase & 104 \\
\hline & $\mathrm{IC}_{50}$ of $\mathrm{I} 3$ and $\mu \mathrm{M}$ & & \\
\hline Crocetin & $\mathrm{IC}_{50}$ of $2.1 \mathrm{mg} / \mathrm{mL}$ & Inhibits pancreatic lipase & 109 \\
\hline Lipstatin & $\mathrm{IC}_{50}$ of $0.14 \mu \mathrm{M}$ & Inhibits pancreatic lipase & 110 \\
\hline Panclicins A, B, C, D E & $2.9,2.6,0.62,0.66$, and $0.89 \mu \mathrm{M}$ & Inhibit pancreatic lipase & 131 \\
\hline Vibralactone & $\mathrm{IC}_{50}$ of $0.4 \mu \mathrm{g} / \mathrm{mL}$ & Inhibits pancreatic lipase & 133 \\
\hline
\end{tabular}

aethanol extract.

Abbreviations: HPL, triacylglycerol acyl hydrolase.

colipase-dependent lipase, classical pancreatic lipase or triacylglycerol acyl hydrolase (HPL), pancreatic lipase relatedprotein 1 and 2 (HPLRP1, HPLRP2), carboxyl ester hydrolase (also known as bile salt stimulated lipase, carboxyl ester lipase, cholesterol esterase, cholesterol ester lipase, human milk lipase, monoglyceride lipase and pancreatic non-specific lipase) and phospholipase A2. ${ }^{17,19}$ Cholesterol esters, lipidic vitamin esters, monoglycerides, diglycerides, TG, and phospholipids are hydrolyzed mainly by carboxyl ester hydrolase. The pancreas also secretes colipase, a factor that is necessary to optimize pancreatic lipase activity. Colipase binds to bile acid micelles and phospholipid-covered emulsions. 
Table 2 Enzyme inhibitors: doses and in vivo effects

\begin{tabular}{|c|c|c|c|}
\hline Product & Dose & Effect & Ref \\
\hline \multirow[t]{5}{*}{ Cetilistat } & $3-100$ mg/kg; DIO rats & $\downarrow$ TG plasma levels & $46,48,49$ \\
\hline & $80-720 \mathrm{mg} /$ day; humans & $\uparrow$ Fat excretion & \\
\hline & & Suppression of body weight gain & \\
\hline & & $\downarrow$ White adipose tissue & \\
\hline & & $\downarrow$ Body weight & \\
\hline \multirow[t]{2}{*}{ Acanthopanax sessiliflorus } & $100-300$ mg/kg; & $\downarrow$ TG plasma levels & 66 \\
\hline & $\mathrm{VO}$, mice & $\uparrow \mathrm{TG}$ in intestinal lumen & \\
\hline \multirow[t]{3}{*}{ Acanthopanax senticosus extracts } & 12 mg/kg; DIO mice & $\downarrow$ TG in liver and serum & 63 \\
\hline & & $\downarrow$ LDL in serum & \\
\hline & & $\uparrow \mathrm{HDL}$ & \\
\hline \multirow[t]{2}{*}{ Panax japonicum total chikusetsusaponins } & I\%-3\% of diet; DIO mice & Suppression of body weight gain & 76 \\
\hline & & $\downarrow$ Parametrial adipose tissue weight & \\
\hline \multirow[t]{3}{*}{ Dioscorea nipponica dioscin and diosgenin } & 100 mg/kg; VO, mice & $\downarrow$ TG in plasma & 72 \\
\hline & $5 \%$ of high fat diet, rats & Suppression of body weight gain & \\
\hline & & $\downarrow$ VLDL and LDL in plasma & \\
\hline \multirow[t]{3}{*}{ Aesculus turbinata } & $0.1 \%-0.5 \%$ of diet; DIO mice & Suppression of body weight gain & 68 \\
\hline & & $\downarrow$ Parametrial adipose tissue weight & \\
\hline & & $\downarrow$ TG in plasma & \\
\hline \multirow[t]{3}{*}{ Cyclocarya paliurus extract } & 250 mg/kg; VO, mice & $\downarrow$ Increase in blood glucose after & 180,181 \\
\hline & & sucrose administration & \\
\hline & & $\downarrow$ TG in plasma & \\
\hline Salacia reticulata extract & 125 mg/kg; VO, Zucker and HFD rats & Suppression of body weight gain & 210 \\
\hline \multirow[t]{2}{*}{ Apple polyphenol and procyanidin fractions } & $200 \mathrm{mg} / \mathrm{kg} ; \mathrm{VO}$, mice & $\downarrow$ TG in plasma after corn oil loading & 97 \\
\hline & $600 \mathrm{mg}$; VO, humans & Inhibition of TG increase after TG load & \\
\hline \multirow[t]{3}{*}{ Nelumbo nucifera } & $5 \%$ of diet; mice & $\downarrow$ Body weight & 199 \\
\hline & & $\downarrow$ TG in plasma & \\
\hline & & $\downarrow$ Parametrial adipose tissue weight & \\
\hline \multirow[t]{2}{*}{ Cassia mimosoides CT-II extract } & $1 \%-3.5 \%$ of diet; DIO rats & Suppression of body weight gain & 98 \\
\hline & & $\downarrow$ Parametrial adipose tissue weight & \\
\hline Peanut shell extract & I\% of diet; DIO rats & Suppression of body weight gain & 207 \\
\hline Carnosic acid & 20 mg/kg; VO, DIO mice & Suppression of body weight gain & 104 \\
\hline \multirow[t]{2}{*}{ Crocetin and crocin } & 50 mg/kg; VO, mice & Suppression of body weight gain & 109 \\
\hline & & $\downarrow$ Epididymal fat pad & \\
\hline Lipstatin & $375-750$ mg/day; humans & $\uparrow$ Fat excretion & 118 \\
\hline \multirow[t]{2}{*}{ Green tea catechins } & $5-80 \mathrm{mg} ; \mathrm{VO}$, rats & Inhibition of $\alpha$-amylase and & 191 \\
\hline & & $\alpha$-glucosidase & \\
\hline
\end{tabular}

Note: ${ }^{\text {a }}$ thanol extract.

Abbreviations: DIO, diet-induced obesity; HFD, high-fat diet; HDL, high-density lipoprotein cholesterol; LDL, low-density lipoprotein cholesterol; TG, triglycerides; VLDL, very-low-density lipoprotein cholesterol; VO, volume overload.

Once bound to these surfaces, colipase facilitates the interaction between pancreatic lipase and the surface of emulsified lipid droplets. ${ }^{20}$ Although HPLRP1 and -2 share a high degree of structural homology and sequence with HPL, ${ }^{21}$ their role in lipid digestion has not been fully clarified. It is known that under physiological conditions HPLRP1 does not exert lipolytic activity. ${ }^{21,22}$ HPLRP2 hydrolyzes galactolipids, ${ }^{23,24}$ phospholipids and TG at a low rate, ${ }^{23}$ and retinyl ester. ${ }^{25}$ HPLRP2 does not need colipase to be active. ${ }^{23}$

The hydrolysis of dietary TG starts in the stomach by the catalytic action of HGL. The secretion of HGL is induced by mechanical stimulation of the stomach, ingestion of food or sympathetic activation. ${ }^{17} \mathrm{HGL}$ hydrolyzes $5 \%$ to $40 \%$ of ingested $\mathrm{TG},{ }^{26}$ mainly generating FFA, diglycerides, and a few 2-MG molecules. ${ }^{27}$ Gastric lipolysis is crucial for the continuation of the digestion process in the duodenum by HPL. Gastric lipolysis ensures: (i) lipid emulsification which creates the lipid-water interface needed for effective lipolysis in the duodenum, ${ }^{27-29}$ (ii) the generation of long-chain FFA which, once in the duodenum, will stimulate the release of cholecystokinin (CCK) and HPL secretion, slowing down gastric emptying, ${ }^{18}$ and (iii) the generation of diglycerides, which are hydrolyzed more effectively than TG. ${ }^{30}$ Therefore, the impact of HPL inhibition on lipid absorption is limited by the activity of HGL. ${ }^{31}$ The hydrolysis of TG persists in the duodenum by means of the combined actions of HGL (HGL 
is responsible for further lipolysis contributing 7.5\% to total lipolysis in the duodenum), HPL and bile salts. HPL is the principal pancreatic lipolytic enzyme; it hydrolyzes $40 \%$ to $70 \%$ of $\mathrm{TG}^{26,28,29}$ yielding 2-MG and long-chain saturated and polyunsaturated FFA as the lipolytic products. ${ }^{16,31,32}$ For full activity under physiological conditions, HPL requires the presence of another pancreatic exocrine protein: colipase. Colipase is secreted as a precursor molecule, in the presence of bile salts, pro-colipase binds, without inducing any conformational change, to the C-terminal domain of the HPL molecule. ${ }^{33}$ In order to be absorbed, bile-derived mixed micelles convert FFA and 2-MG into soluble aggregates. These micelles transport these lipolytic products from the intestinal lumen to the intestinal walls. ${ }^{13,14}$ Once in contact with the enterocyte, the molecules are transported across the cell membrane. The enterocyte re-esterifies 2-MG and FFA into TG, assembles them into chylomicrons and then secretes these into the lymphatic system in order make them bioavailable. ${ }^{19,30,34}$ Lipolysis rates and consequently FFA supply to the body can be affected by several factors such as lipase levels and activity, physicochemical properties of dietary lipids, and the presence of inhibitors or enhancers.

\section{Carbohydrate digestion and absorption}

In humans, between $40 \%$ and $80 \%$ of total caloric intake is accounted for by carbohydrates in their various forms, making them the most important energy source. According to their chemical structure carbohydrates can be classified into absorbable (undigested), digestible, fermentable and non-fermentable forms. ${ }^{35}$ Absorbable carbohydrates (monosaccharides, comprising a single unit such as glucose, galactose, fructose, xylose and ribose) by definition do not need to be digested in order to be transported into the body. However, once a carbohydrate comprises two or more units, it has to be enzymatically digested for it to be absorbed. In the human diet, the main digestible carbohydrates comprise disaccharides such as sucrose (sugar) and lactose, and larger polysaccharides such as starch which constitute a main source of calories in most Western diets. In contrast, fermentable carbohydrates cannot be digested as enzymes cannot readily break the inter saccharide bonds. However, once in the colon these carbohydrates are readily metabolized by colonic bacteria through the process of fermentation. Similarly, if digestible carbohydrates such as sucrose and lactose are maldigested or malabsorbed, they will also be fermented in the large intestine. The main end products of carbohydrate fermentation are short-chain fatty acids (acetate, propionate, and butyrate) and gases (carbon dioxide, hydrogen, and methane). ${ }^{36}$ They can be absorbed in the large intestine (providing energy), used as a bacterial substrate, released as flatus, or excreted as biomass in the feces. Some carbohydrates (such as components of plant cell walls) are neither digested/absorbed nor fermented. They pass through the gastrointestinal (GI) tract mostly unchanged and are eliminated in the feces.

The digestion of carbohydrates begins in the mouth by the action of salivary $\alpha$-amylase, which hydrolyzes the $\alpha-1,4$ bonds in starch, the products of this process are maltose, maltriose, and small dextrins. The starch digestion process continues in the small intestine by the action of pancreatic $\alpha$-amylase. The digestion process is completed by enzymes in the brush border of the small intestine (maltase, sucrase, and lactase, also known as disaccharidases or $\alpha$-glucosidases) which yields the absorbable monosaccharides glucose, fructose, and galactose. A small proportion of monosaccharides can be absorbed passively; however, a carrier protein is required to absorb the amount ingested in a normal diet. ${ }^{37}$

\section{Drugs that interfere with lipid absorption}

Although lipid metabolism is balanced to maintain homeostasis, high-fat diets tend to induce overconsumption and as a consequence, weight gain. This is mainly due to their high energy content and their low potential for inducing satiety. ${ }^{38,39}$ It has been proposed that in the vast majority of cases, overweight and obesity are the consequences of exaggerated consumption of fat rather than carbohydrates. ${ }^{40}$ This does not mean that obesity is not also associated with the consumption of refined sweet carbohydrates, but rather that the intake of this form of carbohydrate is invariably coupled with the intake of dietary fat (in sweet snack foods, sodas and desserts) along with the consumption of high fat savory food items (these often also contain considerable amounts of refined carbohydrates). Given the central role of dietary fat in weight gain, a rational strategy would be to reduce the proportion of calories derived from fat in the diet. In addition to altering dietary intake, the amount of fat entering the body can be reduced by targeting the enzymes involved in lipid digestion and absorption pathways. ${ }^{32}$ Such an approach would have the advantage of reducing energy entering the body without targeting the central nervous system, avoiding the side effect issues that have dogged many appetite-suppressing agents. ${ }^{41}$

The inhibition of fat digestion and absorption is not without side effect issues. As detailed later, GI distress 
and vitamin deficiencies remain a concern with current treatments. However, humans can tolerate a certain degree of inhibition of fat absorption, sufficient to prevent a significant amount of energy entering the body. Given that fat contains $9 \mathrm{kcal} / \mathrm{g}$, the inhibition of the absorption of $30 \mathrm{~g} /$ day would produce a daily deficit of nearly $300 \mathrm{kcal} .{ }^{42}$ This, in addition to a mildly hypocaloric, well-balanced diet, could theoretically produce weight loss of $0.5 \mathrm{~kg} /$ week. Once the excess weight is lost, the therapy could be modified for long-term weight maintenance. For the treatment of hyperlipidemia alone, perhaps even less limited inhibition of fat absorption could produce desirable results. Moreover, the benefits of reducing fat absorption are not restricted to weight loss. Specific reduction of lipid levels in subjects with hyperlipidemias would lead to health benefits beyond those expected through reduction in caloric intake and weight loss alone.

\section{HPL isolated C-terminal domain}

The fact that HPL activates when it forms a complex between its C-terminal region and colipase has brought attention to a relatively new strategy to reduce the activity of HPL. ${ }^{43}$ The isolated C-terminal domain has shown potential HPL inhibitory activity, both in vitro ${ }^{44}$ and in rodents ${ }^{45}$ it behaves as a colipase lure. Studies in humans are required to test the effectiveness of this strategy.

\section{Cetilistat}

Cetilistat (ATL-962, Alizyme ${ }^{\circledR}$; Takeda Pharmaceutical) was developed with the aim of creating a drug similar to orlistat (see below) but without its side effects. Although cetilistat has shown inhibitory activity for both rat and HPL ( $\mathrm{IC}_{50}$ of $54.8 \mathrm{nmol} / \mathrm{L}$ and $5.95 \mathrm{nmol} / \mathrm{L}$ respectively) it can be seen from the $\mathrm{IC}_{50}$ that this component is a much more efficient inhibitor of HPL than rat lipase. Administration of cetilistat (3 to $100 \mathrm{mg} / \mathrm{kg}$ ) to diet-induced obesity (DIO) rats exposed to oral fat loading reduced plasmatic TG elevation with a correspondent increase in fat excretion in a dose dependent manner. This reduced body weight gain and white adipose tissue weight. ${ }^{46}$ A phase I study showed that cetilistat increases fecal fat excretion in a similar way to orlistat but with a better reported tolerability. ${ }^{47}$ Phase IIb studies showed that its administration (180 to $720 \mathrm{mg} /$ day) to obese individuals with and without type II diabetes on a hypocaloric moderate fat diet produced significant weight loss when compared to subjects receiving placebo. ${ }^{48,49}$ The reported adverse effects were similar to those in the placebo group. Despite its reported efficacy and reduced adverse event profile, further development of cetilistat for obesity treatment has been discontinued by Takeda.

\section{Lipase inhibitors from plants}

In the continuing search for novel anti-obesity agents, numerous plant derived phytochemicals have been screened for potential lipase inhibition activity. A recent extensive study examined 132 extracts from 106 plant species, used either as foods or medicinal herbs, screening them for pancreatic lipase inhibition activity. ${ }^{50}$ Surprisingly, the majority of extracts, 100 in total, exhibited some degree of inhibitory activity. All extracts from plants belonging to Brassicaceae, Ericaceae, Fabaceae, Rosaceae and Solanaceae showed inhibitory activity. Twenty-six extracts inhibited lipase activity by at least $40 \%$, of which 10 exhibited over $70 \%$ inhibitory activity. All extracts from apples exhibited more than $70 \%$ inhibitory activity. The current review classifies these botanically derived inhibitors into the following chemical classes.

\section{Saponins}

Saponins are phytochemicals which can be found in the roots and rhizomes of most vegetables, beans and herbs. Saponins are glycosides known for their soap-like foaming ability when mixed with water. This foaming ability results from the combination of a lipophylic sapogenin and a hydrophilic sugar part. ${ }^{51}$ Certain saponins such as oleanane, lupine and dammarane-type can inhibit pancreatic lipase activity and therefore have potential as treatments that could prove effective for obesity and related disorders. ${ }^{52-54}$ However, the clinical potential of saponins remains difficult to judge with such limited clinical data available.

\section{Acanthopanax senticosus (Rupr. Maxim) Harms}

A. senticosus, also known as Siberian Ginseng or Eleutherococcus senticosus, is a shrub commonly found in the northeast of Asia. Crude $A$. senticosus extracts have been used to treat physiological changes induced by stress, ${ }^{55,56}$ some allergic and inflammatory conditions, ${ }^{57,58}$ cancer, ${ }^{59}$ chronic bronchitis, hypertension, ischemic heart disease, and gastric ulcers. ${ }^{60}$ So far, 26 triterpenoid saponins have been isolated from the leaves and fruits of $A$. senticosus ${ }^{52}$ among which ciwujianoside $\mathrm{C}_{1}$, tauroside $\mathrm{H}_{1}, 3-\mathrm{O}$ - $\alpha$-L-rhamnopyranosyl-( $\left.1 \rightarrow 2\right)$ $\alpha$-L-arabinopyranosyl mesembryanthemoidigenic acid, acanthopanaxoside $\mathrm{C}$, acanthopanaxoside $\mathrm{E}$, silphioside $\mathrm{F}$, copteroside $\mathrm{B}$, hederagenin 3-O- $\beta$-D glucuronopyranoside 6'-O-methyl ester and gypsogenin 3-O- $\beta$-D-glucuronide, sessiloside and chiisanoside exhibit pancreatic lipase inhibitory activity in vitro with $\mathrm{IC}_{50}$ values ranging from 0.22 to $0.29 \mathrm{mM} .^{52,61}$ Studies performed in vivo have shown that in DIO rats $^{62}$ and C57BL/6J mice, administration of an A. senticosus extract (12 mg/kg for 12 weeks) decreased 
the deposition of abdominal fat and improved associated lipid parameters, such as increasing serum high-density lipoprotein (HDL) cholesterol, and decreasing serum TG, low-density lipoprotein (LDL) cholesterol, and hepatic TG. ${ }^{63}$ In a placebo controlled study, administration of concentrated extracts of $A$. senticosus (1500 mg/day for 6 months) to postmenopausal women decreased serum LDL levels and LDL/HDL ratios without associated side effects. ${ }^{64}$ However, since $A$. senticosus extracts have several mechanisms of action including the inhibition of hepatic lipogenic enzymes and glucose 6-phosphatase, ${ }^{65}$ the reduction of LDL levels is probably the result of a combination of effects. The effects of $A$. senticosus extract on body mass and body composition remain to be demonstrated.

\section{Acanthopanax sessiliflorus sessiloside and chiisanoside}

These are lupine-type saponins found in the leaves of A. sessiliflorus. In vitro studies have shown that both sessiloside and chiisanoside inhibit HPL activity in a dosedependent manner, with $\mathrm{IC}_{50}$ values of 0.36 and $0.75 \mathrm{mg} / \mathrm{mL}$, respectively. ${ }^{53}$ In mice, simultaneous administration of oil and chiisanoside (100 and $300 \mathrm{mg} / \mathrm{kg}$ ) decreased plasma TG levels and increased the amount of undigested TG in the intestinal lumen. ${ }^{66}$ No clinical data are available on $A$. sessiliflorus.

\section{Aesculus turbinata escins}

A. turbinata (Japanese horse chestnut) is a medicinal plant widely distributed in north western China. Its dried ripe seeds have been employed as a carminative, stomachic, and analgesic for the treatment of distension and pain in the chest and abdomen. ${ }^{67}$ The saponins extracted from the seeds are called escins. Recently, escins have been reported to show inhibition of pancreatic lipase activity $\left(\mathrm{IC}_{50}\right.$ of $\left.24 \mathrm{mg} / \mathrm{mL}\right) .{ }^{68,69}$ Administration of escins ( $0.1 \%$ to $0.5 \%$ of diet) to mice fed a high fat diet prevented body weight gain without altering caloric intake. An increase in the levels of undigested fat in the mice feces confirmed effective inhibition of fat digestion in vivo. ${ }^{70}$ However, to date there are no published clinical data on these effects in humans.

\section{Chinese tea plant saponins}

Studies performed with crude saponins extracted from the flower buds of the Chinese tea plant Camellia sinensis have shown that in mice they accelerate GI transit and also exert an inhibitory effect on pancreatic lipase with an $\mathrm{IC}_{50}$ of $0.091 \mathrm{mg} / \mathrm{mL}$. The main components responsible for these effects are the chakasaponins I, II, and III which inhibit pancreatic lipase with $\mathrm{IC}_{50}$ values of 0.17 to $0.53 \mathrm{mM}$. Such compounds could be valuable in the prevention of obesity, but studies assessing their effect in HPL are needed to assess their potential. ${ }^{71}$

\section{Dioscorea nipponica}

D. nipponica Makino is a herb that grows in the mountainous areas of the Korean peninsula. It has long been used as a popular remedy for the treatment of several diseases including asthma, rheumatoid arthritis and bronchitis. ${ }^{72}$ The extract of $D$. nipponica appears to inhibit porcine pancreatic lipase activity with $\mathrm{IC}_{50}$ values of 5 to $10 \mathrm{mg} / \mathrm{mL}$. Dioscin and its aglycone diosgenin are the result of further purification processes. When administered to mice, both components have been shown to suppress increases of blood TG following oral administration of corn oil. ${ }^{72}$ Rats fed a high fat diet containing $5 \%$ of $D$. nipponica had significantly lower body weight gain that their control counterparts. This was accompanied by decreases in blood TG, very-low-density lipoproteins (VLDL) and LDL. ${ }^{72}$ The effects of $D$. nipponica on body weight have yet to be proven in a clinical study.

\section{Oolong tea saponins}

Three types of tea, green, oolong and black are used all over the world as traditional healthy drinks. Green and oolong tea have been reported to exert anti-obesity and hypolipidemic actions. Black tea also contains many active ingredients; ${ }^{73}$ however some may not survive processing. These teas contain several different active ingredients that may exert anti-obesity actions through various mechanisms. Oolong tea contains two saponins (theasaponins E1 and E2) that seem to competitively inhibit pancreatic lipase activity with $\mathrm{Km}$ and Vmax values of $1.42 \mathrm{mg} / \mathrm{mL}$ and $476.2 \mathrm{nkat} / \mathrm{L}$ respectively. The Ki value of tea saponin is $0.25 \mathrm{mg} / \mathrm{mL} .^{73,74}$ However, to date no studies of in vivo activity of these saponins have been reported.

\section{Panax japonicus chikusetsusaponins}

The rhizomes of $P$. japonicus C.A. Meyer (Japanese name; Chikusetsuninjin), have been used as a folk medicine for hypertension, arteriosclerosis and diabetes. ${ }^{75}$ In vitro total chikusetsusaponins as well as chikusetsusaponin III, 28-deglucosyl-chikusetsusaponin IV and 28-deglucosylchikusetsusaponin vs inhibit pancreatic lipase activity at concentrations of 125 to $500 \mu \mathrm{g} / \mathrm{mL} .{ }^{76}$ One study showed that the administration of total chikusetsusaponins ( $1 \%$ to $3 \%$ in diet) significantly suppressed weight gain in DIO mice. ${ }^{76}$ This effect was independent of energy intake and correlated with a significant reduction in parametrial adipose tissue weight. 
In addition, a reduction of plasma TG levels was observed. ${ }^{76}$ Clinical studies on the effects of chikusetsusaponins on body composition or body mass have yet to be published.

\section{Platycodin saponins}

Platycodin saponins are the main constituents of Platycodi radix. Platycodi radix is the root of Platycodon grandiflorum A. DC (Campanulaceae), commonly known as Doraji. ${ }^{77}$ Some Asian cultures use Platycodi radix in cooking and also as a traditional oriental medicine ingredient. Some evidence shows that Platycodi radix extracts possess some health benefits such as the improvement of hypercholesterolemia and hyperlipidemia. ${ }^{78}$ The saponin-rich fraction of Platycodi radix has an inhibitory effect on HPL and this seems to correlate with anti-obesity actions. ${ }^{79-82}$ Among the various saponins, platycodin D possesses the strongest HPL inhibitory activity with a $\mathrm{Ki}$ of $0.18 \mathrm{mM}{ }^{82}$ Nevertheless, a study by Zhao et $\mathrm{al}^{83}$ found that in rats, the decrease in body weight correlated with decrease in caloric intake, an effect not obviously attributable to lipase inhibition. They ascribed this effect to the ability of Platycodin saponins to reduce gastric secretion, ${ }^{84}$ which in turn would slow gastric digestion, decreasing subsequent food intake. These results, taken together, suggest that Platycodin saponins provide a potential alternative treatment for both obesity and hyperlipidemia. ${ }^{80,81}$ However, further data showing replication of these effects in humans are needed.

\section{Sapindus rarak DC}

$S$. rarak is a tree found in South and Southeast Asian countries. The pericarps have anti-pruritic actions. ${ }^{85} \mathrm{~A}$ recent in vitro study has shown that the methanolic extract from $S$. rarak pericarps exerts pancreatic lipase inhibitory activity $\left(\mathrm{IC}_{50}=614 \mu \mathrm{g} / \mathrm{mL}\right)$. This extract contains several saponins of which rarasaponins I and II and raraoside A inhibited pancreatic lipase with $\mathrm{IC}_{50}$ of $131 \mu \mathrm{M}, 172 \mu \mathrm{M}$ and $151 \mu \mathrm{M}$ respectively. ${ }^{86}$ The in vivo effects of $S$. rarak saponins remains yet to be investigated.

\section{Scabiosaponins}

Scabiosa tschiliensis Grun. (Dipsacaceae) is a perennial herb widely distributed in Mongolia and China. S. tschiliensis flowers are traditionally used as a remedy for headache, fever, cough, and jaundice. ${ }^{87}$ In vitro studies have reported that scabiosaponins E, F, G and I, hookeroside A and B, and prosapogenin $1 \mathrm{~b}$ inhibit HPL. Of these, prosapogenin $1 \mathrm{~b}$ reportedly possesses the greater inhibitory activity at a concentration of $0.12 \mathrm{mg} / \mathrm{mL}$. This dose produced lipase inhibitory activity comparable to $0.005 \mathrm{mg} / \mathrm{mL}$ of orlistat in the same model. ${ }^{87}$ The fact that to date no studies in vivo have been reported could be due to the difficulties in isolating these compounds. However, recently scabiosaponins E, F, and $\mathrm{G}$ have been successfully synthesized. ${ }^{88}$

\section{Polyphenols}

Polyphenols are chemical compounds characterized by the presence of more than one phenol unit or building block per molecule. Fruit skins contain high levels of polyphenols. The health benefits of specific polyphenols are well-documented. Polyphenols possess antioxidant actions and are also able to inhibit digestive enzymes, these two actions could lower the risk of cardiovascular disease and cancer. ${ }^{89}$ Naturally occurring polyphenols, and in particular catechins and condensed tannins isolated from various plant sources, have been shown to inhibit digestive enzymes including lipase and $\alpha$-amylase in vitro ${ }^{90-92}$ and therefore have some potential in the management of obesity.

\section{Apple polyphenols}

Apples contain several phenolic substances (ie, chlorogenic acid, (+)-catechin, epicatechin, phloridzin, rutin, and procyanidins (condensed tannins). ${ }^{93}$ Procyanidins in apples are mainly composed of various polymerized catechins. Apples and their polyphenol (AP) extract have several biological activities such as antioxidant, ${ }^{94}$ anti-allergy ${ }^{95}$ and anti-tumor activity. ${ }^{96}$ In a recent study performed by Sugiyama et $\mathrm{al}^{97}$ it was found that AP inhibited pancreatic lipase activity in a dose-dependent manner with an $\mathrm{IC}_{50}$ value of $5.6 \mu \mathrm{g} / \mathrm{mL}$. In addition, the procyanidin fractions extracted from AP also inhibited pancreatic lipase activity in a dose-dependent manner with an $\mathrm{IC}_{50}$ value of $1.4 \mu \mathrm{g} / \mathrm{mL}$. In mice, AP administration $(200 \mathrm{mg} / \mathrm{kg})$ significantly decreased plasma TG after corn oil loading. The procyanidin fraction also tended to inhibit TG absorption as compared with the control group. Administration of AP (600 mg) containing capsules to humans inhibited TG elevation after TG load when compared to subjects receiving placebo. No side effects were reported. ${ }^{97}$

\section{Cassia mimosoides L. var nomame Makino}

(Nomame Herba)

C. mimisoides is a leguminous plant grown in Japan and China. Its ethanol extract, CT-II, possesses a dose dependent inhibitory action on porcine lipase. ${ }^{98}$ When administered to rats fed high fat diets, CT-II ( $1 \%$ to $3.5 \%$ of diet) dose dependently suppressed body weight gain, and lowered parametrial fat and liver weight when compared to control animals. ${ }^{98}$ The effects of CT-II on body weight in humans have yet to be reported. 


\section{Grape seed extracts}

Grape seeds and skins contain a variety of health-promoting polyphenols, also known as condensed tannins or proanthocyanidins. ${ }^{99}$ Currently these polyphenols are the focus of research to elucidate their putative beneficial effects. ${ }^{100} \mathrm{Grape}$ seed extract at a concentration of $1 \mathrm{mg} / \mathrm{mL}$ inhibits $80 \%$ of lipase activity. ${ }^{101}$ Importantly, in vivo these extracts seem to lack toxicity. Further studies in animal models are needed to evaluate it potential as a weight loss product. ${ }^{102}$

\section{Terpenes}

Terpenes are a large class of hydrocarbons, produced by a broad variety of plants. Chemical modification of terpenes yields terpenoids. Both terpenes and terpenoids are the main constituents of the essential oils of many plants. These include carnosic acid, carnosol, crocin and crocetin.

\section{Carnosic acid and carnosol}

Carnosic acid and carnosol are compounds extracted from the leaves of Salvia officinalis L. (sage). Both substances exert inhibitory activity on pancreatic lipase with $\mathrm{IC}_{50}$ values of 36 and $13 \mu \mathrm{M}$, respectively. Although carnosol possesses the stronger inhibitory activity in vitro, in vivo it seems to lack substantial effects. This has been attributed to its instability in suitable solvents. ${ }^{103}$ Administration of carnosic acid (20 $\mathrm{mg} / \mathrm{kg} / \mathrm{day}$, by mouth) to mice fed a high fat diet, it reduced body weight gain and the accumulation of epididymal fat. ${ }^{104}$ To date studies in humans are lacking.

\section{Crocin and crocetin}

Gardeniae fructus is used as a Chinese traditional medicine mainly for its analgesic and antipyretic effects. It contains geniposide and crocin as main components. ${ }^{105}$ These components exhibit antioxidant, antitumoral and neuroprotective effects. ${ }^{106-108}$ In vitro, crocin and its metabolite crocetin potently inhibit pancreatic lipase. The most potent inhibitor was crocetin, with an $\mathrm{IC}_{50}$ value of $2.1 \mathrm{mg} / \mathrm{mL} .{ }^{109} \mathrm{In}$ mice fed a high fat diet, crocetin and crocin inhibited the incremental increase in body weight compared with that of the control group. These compounds also significantly reduced epididymal fat pad mass. Their potency at a dose of $50 \mathrm{mg} / \mathrm{kg}$ is comparable with that of orlistat at a dose of $10 \mathrm{mg} / \mathrm{kg} .{ }^{109}$ Crocin and crocetin have yet to be tested in a clinical trial.

\section{Lipase inhibitors derived from microbial sources Lipstatin}

Lipstatin, a compound isolated from Streptomyces toxytricini, is a very potent and selective irreversible inhibitor of pancreatic lipase. $\mathrm{The}_{\mathrm{IC}}$ of lipstatin for pancreatic lipase is $0.14 \mu \mathrm{M} .{ }^{110}$ Tetrahydrolipstatin or orlistat (THL, Ro 18-0647, Xenical $^{\circledR}$; Hoffmann-La Roche, Basel, Switzerland) is a highly lipophilic hydrogenated derivative of lipstatin. ${ }^{111,112}$ Orlistat is a potent inhibitor of most mammalian lipases. Therapeutic doses of orlistat generally achieve around 35\% inhibition of lipid digestion. ${ }^{11,113,114}$ Thus as a consequence the undigested fat is not absorbed but excreted. ${ }^{115}$ Beyond its lipase inhibition activity, orlistat reportedly does not significantly diminish the activity of other intestinal enzymes. Less than $1 \%$ of orlistat itself is absorbed, preventing inhibition of extra intestinal lipases. ${ }^{116}$ When administered by intraduodenal infusion in a rat model it almost completely inhibited the absorption of cholesterol. ${ }^{117}$ In humans, initial studies showed that orlistat administration at doses between 375 and $750 \mathrm{mg} /$ day decreased fat absorption and therefore increased fat elimination which caused side effects related to the amount of fat in the diet. In both rodent and human participants short-term orlistat administration increases fecal fat loss which returns to baseline after cessation of dosing. ${ }^{116,118,119}$ This product has been evaluated in many clinical studies for obesity treatment. After 1 year treatment, the combination of orlistat (120 mg taken three times daily just before feeding) and a hypocaloric diet produced a higher weight loss compared with placebo. ${ }^{120,121}$ Although the weight reduction from baseline was no greater than $10 \%$ ( $4 \%$ placebo subtracted), ${ }^{120,121}$ orlistat significantly decreased glycemia, glycated hemoglobin, insulin resistance and cardiovascular disease risk factors such as hyperlipidemia and high blood pressure. ${ }^{122,123}$ It is not yet known how quickly weight is regained on cessation of treatment, however in trials in which patients were re-randomized to placebo after one year of treatment they regained some but not all of the weight lost from baseline. ${ }^{124}$ In the UK, Clinical Excellence guidelines currently recommend that orlistat should not be continuously used for more than 24 months. ${ }^{125}$ Such precautions are advisable because of the limited data available on the effect of orlistat administration for longer than two years (only the XENDOS study administered the drug continuously for 48 months) and side effect issues. Specifically, orlistat has shown to slightly impair the absorption of liposoluble vitamins $A, E$, and $\beta$-carotene, ${ }^{116,126}$ however, vitamin supplementation is only required in a minority of patients. Orlistat accelerates gastric emptying, this could lead to exaggerated postprandial hyperglycemia, ${ }^{127}$ and the presence of undigested fat in the bowels causes side effects (such as diarrhea, abdominal pain, oily stools and fecal spotting) that limit use of orlistat. ${ }^{128}$ Additionally, chronic GI ailments like irritable bowel syndrome are clear contraindications for its use. These 
issues, along with the potential for abuse of this drug as a purgative, have caused some concern. Nonetheless, a half dose of orlistat $\left(\mathrm{Alli}^{\circledR}\right.$, $60 \mathrm{mg}$ rather than $120 \mathrm{mg} 3$ times daily) has been approved in Australasia, USA and the EU for over-the-counter use. ${ }^{128}$ Data from very recent studies report that the administration of half dose of orlistat in conjunction with a reduced calorie, lower-fat diet to overweight and obese participants significantly reduced their body weight $(5.96 \mathrm{~kg}$ vs $3.91 \mathrm{~kg}$ ) waist circumference and visceral fat (15.7\% vs 9.4\%). ${ }^{129,130}$ It is important to note that both studies this dose was well tolerated by participants. To summarize, orlistat in conjunction with behavioral modifications could become useful therapies for the treatment of obesity and/or hyperlipidemia. ${ }^{118}$

\section{Panclicins}

Panciclins A, B, C, D, and E are pancreatic lipase inhibitors isolated from Streptomyces sp. NR 0619. Structurally, panclicins A, B, C, D, and E are analogs (but not irreversible inhibitors) of tetrahydrolipstatin, which contains a $\beta$-lactone and an N-formyl leucine ester. The $\mathrm{IC}_{50}$ of panclicins $\mathrm{A}, \mathrm{B}$, $\mathrm{C}, \mathrm{D}$, and $\mathrm{E}$ for porcine pancreatic lipase are 2.9, 2.6, 0.62, 0.66 , and $0.89 \mu \mathrm{M}$, respectively. ${ }^{131}$ To date, no studies in animal models have been performed.

\section{Ebelactones}

Ebelactone B, which is obtained from Streptomyces aburaviensis, produces potent inhibition of pancreatic lipase. When administered (10 mg/kg, $60 \mathrm{~min}$ prior to feeding) to rats fed a high fat diet, it inhibited fat intestinal absorption in a dose-dependent manner. It also decreased plasmatic levels of TG and cholesterol. No data on animal weight or adiposity are reported. ${ }^{132}$

\section{Vibralactone}

Vibralactone is a compound isolated from the culture broth of the polypore Boreostereum vibrans. In vitro it inhibits pancreatic lipase with an $\mathrm{IC}_{50}$ of $0.4 \mu \mathrm{g} / \mathrm{mL} .{ }^{133}$ Studies in animal models are required to test vibralactone's effectiveness and possible undesirable effects.

\section{Drugs that interfere with carbohydrate absorption}

Inhibition of $\alpha$-amylase and brush border disaccharidases would lead to decreased absorption of all the main carbohydrates in the diet (glucose absorption would not be affected). This in theory would have several benefits, as blocking these enzymes would decrease the absorption of calories thereby promoting weight loss. These compounds have pharmacological potential for helping with weight loss and then maintaining weight without a dramatic reduction in carbohydrate intake. In addition, since carbohydrate absorption is affected, these products would reduce the magnitude of postprandial glucose and insulin responses to dietary carbohydrates. The modulation of this response could prove to be clinically useful in the management of diabetic individuals. $\alpha$-amylase inhibition delays gastric emptying by increasing the amount of undigested carbohydrate in the ileum. ${ }^{134,135}$ Therefore, amongst other effects, amylase inhibition could modulate GI function and gut peptide release, strengthening satiety and decreasing food intake by mechanisms including reduced gastric emptying.

\section{Acarbose}

Acarbose (Bay g 5421, Glucobay ${ }^{\circledR}$, Precose $^{\circledR}$, Prandase ${ }^{\circledR}$; Bayer) is a pseudotetrasaccharide that inhibits intestinal $\alpha$-glucosidase reversibly at the brush border of intestinal mucosa. As a consequence, the transformation of disaccharides to monosaccharides is prevented, the uptake of monosaccharides is retarded and thus postprandial insulin and glucose levels are reduced. ${ }^{136,137}$ A study by Samulitis et al ${ }^{138}$ showed that in vitro, acarbose $(4 \mu \mathrm{M})$ strongly inhibited the activities of $\alpha$-amylase and sucrase (98 and 63\%, respectively). At a higher concentration $(200 \mu \mathrm{M})$ it also inhibited isomaltase activity (28\%) with negligible effects on trehalase and lactase activities. Reported adverse reactions are rare with this drug. Gradual dose increments prevent GI side effects. Studies in rats have reported a dose-dependent reduction of weight gain. ${ }^{139}$ The administration of acarbose to weight-reduced women limited weight regain. ${ }^{140}$ In a one year, double-blind, randomized, placebo-controlled study in type 2 diabetes subjects, the individuals receiving acarbose lost $0.5 \mathrm{~kg}$ while the placebo group gained $0.3 \mathrm{~kg} .{ }^{141}$ Administration of acarbose (150 mg/day) to women with polycystic ovary syndrome significantly reduced body weight and BMI. ${ }^{142-144}$

\section{Deoxynojirimycin (DNJ)}

DNJ is a polyhydroxylated alkaloid isolated from mulberry trees which act as a competitive inhibitor of small-intestinal brush-border $\alpha$-glucosidase. ${ }^{145}$ Recent reports have considered sericulture products containing DNJ to be suitable for use as functional foods and food additives. In diabetic rats, the administration of DNJ (20 mg/kg) prevents weight gain. ${ }^{146}$ Synthetic derivatives of DNJ have been developed; they include competitive inhibitors BAY o 1248 (emiglitate) and BAY m 1099 (miglitol). In vitro, both compounds are very 
potent $\alpha$-glucosidase inhibitors. At doses ranging from 0.1 to $5 \mu \mathrm{g} / \mathrm{mL}$, they inhibit sucrase (up to $97 \%$ ) and glucoamylase (up to $96 \%$ ). BAY m 1099 also reduced lactase activity (up to $56 \%$ ). Interestingly, none of these compounds seem to inhibit $\alpha$-amylase. In contrast to acarbose, the DNJ derivatives at high concentrations (20 to $200 \mu \mathrm{M}$ ) considerably inhibited trehalase and lactase (a $\beta$-galactosidase) activities. ${ }^{138}$ When administered to diabetic rats, BAY o 1248 inhibited weight gain in animals fed a diet high in starch while it did not have any effect on animals fed with glucose. ${ }^{147}$ In support of findings obtained from animal experiments, BAY o 1248 (10 mg) and BAY m 1099 (50 mg) delayed sucrose absorption and prevented post prandial increases in glucose in healthy male volunteers. ${ }^{148}$ However, $60 \%$ of participants reported intestinal side effects such as flatulence and diarrhea, ${ }^{149}$ an undesirable effect due to increased amounts of fermentable (undigested) carbohydrates.

\section{Extracts of black, green, and mulberry teas}

In vitro studies suggest that extracts of black, green, and mulberry teas could interfere with carbohydrate and TG absorption due to their ability to inhibit $\alpha$-amylase, ${ }^{150} \alpha$-glucosidase, ${ }^{151}$ sodium-glucose transporters, ${ }^{152}$ and pancreatic lipase. ${ }^{153}$ Administration of a combination of green $(0.1 \mathrm{~g})$, black $(0.1 \mathrm{~g})$, and mulberry $(1.0 \mathrm{~g})$ tea leaves which contained approximately $5 \mathrm{mg}$ DNJ-type compounds, $100 \mathrm{mg}$ epicatechin gallate, $300 \mathrm{mg}$ epigallocatechin gallate, and $100 \mathrm{mg}$ theaflavin to humans reduced carbohydrate (derived from starch) absorption by $25 \% .{ }^{153}$ To date, no in vivo studies have been carried out.

\section{Phaseolus vulgaris $\mathrm{L}$.}

The purified, non-toxic (P. vulgaris contains toxic substances) extract of $P$. vulgaris (kidney bean) contains large amounts of phaseolamine (Phase $2^{\circledR}$; previously sold as Phaseolamin $2250^{\circledR}$, referring to $1 \mathrm{~g}$ of the product blocking $2250 \mathrm{starch}$ calories, DEcarb $\left.{ }^{\circledR}\right)$, a glycoprotein that inhibits $\alpha$-amylase in a non competitive manner. ${ }^{154,155}$ In the US, several different preparations are commercially available for the treatment of obesity. In vitro studies have demonstrated that phaseolamine binds to $\alpha$-amylase forming a 1:1 complex inhibiting the enzyme. In rats intragastric phaseolamine administration reduces post-prandial as well as basal plasma glucose levels. ${ }^{156-158}$ In addition, phaseolamine reduces food intake and consequently body weight. ${ }^{139,157,159,160}$ Apart from the inhibition of $\alpha$-amylase, $P$. vulgaris extract seems to stimulate $\mathrm{CCK}$ release, and interfere with central mechanisms that regulate food intake and food palatability. ${ }^{161}$ Administration of large doses of phaseolamine impairs the growth rate of rats. ${ }^{162}$ Studies performed in humans have shown contradictory results. For instance, three studies have failed to show any measurable inhibition of starch hydrolysis or significant weight loss in vivo, ${ }^{155,163-165}$ suggesting either the existence of an alternate route capable of degrading starch or insufficient amounts of inhibitors reaching the substrate. Subsequent studies showed that intraduodenal administration of the partially purified inhibitor significantly inhibited $\alpha$-amylase activity during the ingestion of a starch diet. ${ }^{166}$ Additional studies in normoglycemic and diabetic individuals found that phaseolamine administration produced an earlier reduction of postprandial glucose levels than controls, with 57\% lower glucose absorption. ${ }^{167,168}$ Acute administration of $1.5 \mathrm{~g}$ of phaseolamine to healthy participants blocked the absorption of $66 \%$ of carbohydrates present in a standard meal. ${ }^{169}$ A 30-day, double-blind, placebo-controlled clinical trial for weight loss that compared Phase 2 versus placebo reported a $4 \%$ loss of body weight compared with $0.47 \%$ in the placebo group. This was accompanied by a $10 \%$ reduction in body fat in the experimental group. ${ }^{170}$ In 2007 , Celleno et $\mathrm{al}^{171}$ and Udani and Singh ${ }^{172}$ conducted randomized, double-blinded, placebo-controlled studies on normal and overweight male and female volunteers during which some participants were prescribed a high carbohydrate diet. After 1 month of chronic administration (445 to $1000 \mathrm{mg} /$ day) participants receiving P. vulgaris extract showed a significant reduction in both total body mass and BMI compared to control, accompanied by changes in body composition. This was shown by significant reductions in total fat mass, fat deposition, and waist/hip/ thigh circumferences while maintaining lean body mass. At the moment, the long-term consequences of intraluminal amylase inhibition are not known. Therefore longer studies with a larger pool of subjects are required to investigate these effects and validate the above-mentioned findings.

\section{Both anti-lipase and anti-amylase activity Berry polyphenols}

Berry polyphenols, such as anthocyanins and ellagitannins have been shown to reduce postprandial hyperglycemia. ${ }^{173}$ Although in vitro anthocyanins can directly induce secretion of insulin from pancreatic cells, ${ }^{174}$ their main effect on postprandial hyperglycemia seems mainly due to inhibition of $\alpha$-glucosidase and $\alpha$-amylase. ${ }^{175}$ In addition, in vitro this extract also exerts inhibitory activity on pancreatic lipase. Ellagitannin-rich extracts such as (raspberry, strawberry, cloudberry and arctic bramble) seem to be the most effective 
at inhibiting lipase. ${ }^{176}$ Some published data suggest that extract-induced fecal lipid excretion is associated with reductions in weight gain and changes in TG metabolism, ${ }^{97,177}$ while other studies report no significant correlations. ${ }^{178}$ The lack of effects found in some studies could be due to compensatory increases in lipase secretion similar to those seen in studies on condensed tannins in rats. ${ }^{90}$ The demonstration of lipase inhibition in vivo by berry components needs to be fully demonstrated before there can be any serious investigation of their weight management potential.

\section{Cyclocarya paliurus (Batal.) Iljinskaja}

C. paliurus is a tree found in the highlands of southern China. It is used as a folk remedy for several ailments. Cyclocarioside A, II and III are triterpenoid saponins isolated from the leaves of C. paliurus. It is known that triterpenoid saponins exhibit an insulin-like activity in adipocytes, in vivo and in vitro. ${ }^{179}$ Therefore, this could be one mechanism responsible for the beneficial effects of these compounds. In vitro, C. paliurus extract showed inhibitory activity toward pancreatic lipase, with an $\mathrm{IC}_{50}$ of $9.1 \mu \mathrm{g} / \mathrm{mL} .{ }^{180}$ Administration of C. paliurus extract $(250 \mathrm{mg} / \mathrm{kg})$ to mice after a load of dietary fat suppressed the expected increase in plasma triacylgycerol levels. ${ }^{180}$ Taken together these results suggest that the hypolipemic action of C. paliurus extract is probably due to lipase inhibition. In vitro studies have shown $\alpha$-glucosidase inhibitory activity at the dose of $5 \mu \mathrm{g} / \mathrm{mL}$. Administration of a C. paliurus extract $(250 \mathrm{mg} / \mathrm{kg})$ to mice suppressed the expected increase of blood glucose level following sucrose administration. ${ }^{181}$ In addition, the oscillations in blood glucose levels found in genetically hyperglycemic obese KK-AY mice were significantly lower when C. paliurus ( $2 \mathrm{~g} /$ day) extract was administered daily for 3 weeks. To date, no research has been conducted on the hypoglycemic effect of this extract in clinical settings

\section{Green tea}

In Asia, green tea is widely consumed and for centuries has been thought to exert significant health promoting effects. ${ }^{182}$ The long-term consumption of green tea and its extract (GTE) (commercially available as pills, patches, gums, mints, extracts, and ice creams) has been associated with weight loss mainly through a thermogenic mechanism. ${ }^{183}$ Compared to other teas, green tea catechins have been the most extensively investigated. Because green tea is derived from an oxidation-free process, high levels of catechins are retained. In contrast, the full fermentation processes used to produce black tea significantly reduce catechins levels. ${ }^{184}$ The main active ingredients in GTE: the catechins epigallocatechin gallate (EGCG; Teavigo ${ }^{\circledR}$ ), epigallocatechin (EGC), epicatechin gallate (ECG), and epicatechin (EC) are responsible for many of the beneficial effects of green tea. ${ }^{185,186}$ In vitro data suggest that the anti-obesity effects of green tea could in part be mediated through the inhibition of adipocyte division and maturation. ${ }^{187-189}$ There is also evidence that green tea could reduce glucose and fat absorption by inhibiting GI enzymes involved in nutrient digestion. ${ }^{190,191}$ Juhel et al ${ }^{192}$ reported that in vitro the green tea extract AR25 (Exolise ${ }^{\circledR}$; standardized at $25 \%$ catechins) effectively inhibited gastric and pancreatic lipase activities. In addition, tea polyphenols have been shown to inhibit $\alpha$-amylase and $\alpha$-glucosidase in vitro. ${ }^{191}$ It has been shown that green tea catechins reduced $\alpha$-amylase and sucrase activities in rat intestine. ${ }^{191}$ A study performed in streptozotocin-induced diabetic rats showed that addition of green tea extracts to the $\operatorname{diet}(0.01 \%$ and $0.2 \%$ of diet) significantly reduced maltase (both doses) as well as saccharase and lactase (higher dose) activities. ${ }^{193}$ Administration of green tea extract (3\% of diet) to rats fed a high fat diet decreased body weight gain and visceral fat accumulation, this correlated with an increase in fecal lipids. ${ }^{194}$ An open study carried out in moderately obese patients showed that administration of AR 25 for 3 months decreased body weight and waist circumference by $4.6 \%$ and $4.48 \%$ respectively. ${ }^{195}$ Again, these effects could be the result of the aforementioned combination of enzyme inhibition and increased thermogenesis.

\section{Nelumbo nucifera extract (NNE)}

$N$. nucifera Gaertn. is a large aquatic herb widely found in India and China. Its extracts seem to have anti-inflammatory, ${ }^{196}$ antipyretic ${ }^{197}$ and antioxidant properties. ${ }^{198}$ In vitro studies have shown that NNE inhibits lipase and $\alpha$-amylase activity with an $\mathrm{IC}_{50}$ value of $0.46 \mathrm{mg} / \mathrm{mL}$ and $0.82 \mathrm{mg} / \mathrm{mL}$ respectively. This effect was dependent upon the phenolic compounds present in the extract since its elimination abolished NNE inhibitory activity. ${ }^{199}$ In DIO female mice, treatment with NNE (5\% of diet) and exercise decreased body weight, parametrial adipose tissue weight and liver TG levels, this effect was not seen in the exercise only group. ${ }^{199}$ Oral administration of NNE to glucose-fed hyperglycemic and streptozotocin-induced diabetic rats markedly reduced blood sugar levels when compared with control animals. In normal animals, NNE administration improved glucose tolerance and potentiated the action of exogenously injected insulin. To date no studies in humans have been reported. ${ }^{200}$ 


\section{Oolong tea catechins}

Catechins in oolong tea are reported to prevent DIO by inhibiting small intestine micelle formation, ${ }^{201}$ limiting the absorption of sugars by inhibiting $\alpha$ - glucosidase activity. ${ }^{202}$ Epigallocatechin 3-O-gallate (EGCG) is one of the main polyphenols in oolong tea. In vitro, it inhibits pancreatic lipase with an $\mathrm{IC}_{50}$ of $0.349 \mu \mathrm{M}$. In addition, flavan-3-ol digallate esters, such as (-)-epigallocatechin-3,5-digallate also possess inhibitory lipase activity with an $\mathrm{IC}_{50}$ of $0.098 \mu \mathrm{M} .{ }^{203}$ In DIO mice, oolong tea catechins suppressed increases in body weight, parametrial adipose tissue weights, and adipose cell size by delaying the absorption of dietary fat from the intestine by inhibiting pancreatic lipase activity. ${ }^{73}$ In a double-blind, placebo-controlled study, 12 weeks daily administration of oolong tea (containing $690 \mathrm{mg}$ of catechins) to normal and overweight males (with daily EI set at $90 \%$ ) produced a significant reduction in body weight (1.5\%), BMI (1.5\%), waist circumference $(2.0 \%)$, and body fat mass (3.7\%), compared to the placebo group. ${ }^{204}$ These results suggest that oolong tea catechin consumption might be useful as an adjuvant during weight loss programs.

\section{Peanut and peanut shell extract (PSE)}

An aqueous extract of peanut cotyledons has shown specific inhibitory activity towards pancreatic and human salivary $\alpha$-amylases ${ }^{205}$ and lipases. ${ }^{206}$ The peanut shell extract also shows inhibitory effects on human lipase, with a dose of $10 \mathrm{mg} / \mathrm{mL}$ inhibiting $92 \%$ of activity. ${ }^{207}$ When administered as $1 \%$ of a high fat diet, PSE reduced weight gain in normal adult rats without altering food consumption. ${ }^{207}$

\section{Salacia reticulata}

S. reticulata is a climber found in Sri Lanka and India. Its stems and roots are used for diabetes treatment. In Japan, S. reticulata extract is consumed as a food supplement that suppresses postprandial hyperglycemia. The main compounds responsible for $\alpha$-glucosidase inhibition are salacinol $^{208}$ and kotalanol. ${ }^{209}$ S. reticulate polyphenol extracts also inhibit pancreatic lipase with an $\mathrm{IC}_{50}$ of $264 \mathrm{mg} / \mathrm{L}$, and among the constituents isolated from $S$. reticulata, catechins showed potent inhibitory activity. ${ }^{210}$ Studies performed in Zucker rats and high-fat diet rats have shown that the oral administration of a $S$. reticulata extract $(125 \mathrm{mg} / \mathrm{kg})$ suppressed body weight gain without affecting food intake. ${ }^{210}$ To date no human studies have been carried out.

\section{Salix matsudana}

S. matsudana (Chinese willow) (one ingredient of Rev Hardcore $^{\circledR}$ and Methyl Ripped $\left.{ }^{\circledR}\right)$ is a species of willow native to north western China. Its leaves have been used in traditional Chinese medicine for the treatment of several ailments. It has recently been reported that the polyphenol extracts of S. matsudana have anti-obesity actions. ${ }^{211,212}$ These studies showed that oral administration of polyphenol fractions to DIO mice reduced adiposity and body weight. In vitro analysis revealed that $S$. matsudana extract inhibited the enzyme $\alpha$-amylase. In addition, the polyphenol fractions also had an effect on lipid absorption since its presence completely inhibited the intestinal absorption of palmitic acid, a product of oil hydrolysis. The effects of $S$. matsudana are mainly due to the inhibition of carbohydrate and lipid absorption, and the acceleration of fat mobilization through enhancement of NA-induced lipolysis in adipocytes. ${ }^{211}$ Although S. matsudana extracts have been shown to have anti-obesity actions in vitro and in rodents, research in humans, especially on the long term effects, is lacking.

\section{Conclusion}

Blocking the digestion and absorption of dietary lipids and carbohydrates provides a valuable alternative to other pharmacological approaches to obesity. With the recent withdrawal of sibutramine from the European market, the only globally licensed anti-obesity drug remaining is the lipase inhibitor orlistat. This lipase inhibitor has also now been licensed in many countries for over-the-counter, nonprescription weight control. Clinical data suggest that lipase inhibition produces greater than anticipated reductions in diabetes and cardiovascular risk factors than would be expected to be produced by its effects on body weight alone. However, the effect of blocking lipase action on meal induced satiety signals may produce counterproductive effects on appetite. The clinical implications of this have yet to be determined.

Studies in obese patients suggest that lipase inhibitors may be particularly beneficial for those who can effectively control their food intake and adhere to diet restriction. However for those with more dysregulated eating behavior, appetitesuppressing pharmacotherapy might be more efficacious. The role of lipase inhibition induced GI side effects in clinical weight loss remains to be determined. Do those who use lipase inhibitors learn to avoid dietary fat? Or do they learn to avoid taking the prescription as intended - for example regularly missing doses before the consumption of high fat meals? Little evidence exists on the effects of lipase inhibition on dietary compliance and claims based on this lack substantiation. However, if lipase inhibition does produce beneficial changes in behavior through GI-related side effects, the development of side effect-free lipase inhibitors will be pointless. 
For blocking of the inhibition of carbohydrate digestive enzymes, the so-called starch blockers have been available for many years. To date, none of these agents have made a significant contribution to the effective management of obesity. Nonetheless, such products appear to produce beneficial effects on blood glucose levels and may have benefits in obese diabetic populations. Like lipase inhibitors, these agents will not cross the blood-brain barrier and produce CNS related side effects as with traditional appetite suppressant/anti-obesity medication, or nausea associated with newer incretin-based treatments for obesity and diabetes. A major consequence of blocking digestion of carbohydrates in the proximal gut, colonic fermentation, can only lead to increased microbial production of gas in the bowel. The effects of starch blockers on appetite immediately postmeal might weaken those processes of satiety dependent on rapid glucose absorption (during and immediately post-meal). However colonic fermentation may increase late post meal satiety signals mediated by the release of short-chain FFA such as GLP-1 and PYY, and FFA oxidation in the liver. Overall, it can be concluded that no single compound can be considered to be a proven weight control product. Although some of the products reviewed above show potentially promising effects for weight control, for the majority more data are needed to define safety, the optimal dose required, and the actual magnitude of effects that can be expected during use in practice. Moreover, many of these substances may also produce adverse side effects.

For the majority of compounds described here, there are tantalizing but still inconsistent or incomplete data relating to the mechanism of action and benefits for weight control. In the majority of cases effects have been demonstrated in vivo or to a lesser extent in animal models. For lipase inhibitors, although the majority of plant derivatives exert in vitro inhibitory activity, the most promising compounds seem to be those derived from bacterial sources such as lipstatin and its synthetic derivative orlistat. These compounds have proven to reduce body weight in humans without significant side effects. In terms of the inhibition of carbohydrate digestive enzymes, the products that have so far been used with some degree of success in humans for the purpose of weight reduction are acarbose and phaseolamine, the remaining products are still in experimental phases. Finally, some phytochemicals such as green and oolong tea extracts, which inhibit both lipid and carbohydrate digestive enzymes, seem to have some beneficial effects as weight-controlling products.

Improved understanding and evidence on each of the reviewed and other proposed weight control ingredients will guide further research, as well as the selection of ingredients and product formats that can deliver the most attractive and effective benefits to consumers. Ultimately, only randomized, double blinded, placebo-controlled clinical trials of enzyme inhibitors in humans can demonstrate their true potential. For all ingredients purported to be useful in weight control, significant placebo-subtracted weight loss needs be demonstrated at least in the medium term, ie, up to 24 weeks of use. Nonetheless, inhibition of the breakdown of carbohydrate and fat in the GI tract remains a viable means of reducing energy absorption and thus overall energy intake. As such they may prove useful agents in weight management.

\section{Disclosures}

The authors declare no conflicts of interest.

\section{References}

1. Bray GA. Medical consequences of obesity. J Clin Endocrinol Metab. 2004;89:2583-2589.

2. WHO/Europe. The challenge of obesity in the WHO European Region. 2005, WHO: Copenhagen, Bucharest

3. WHO. Obesity and overweight; Geneva: WHO; 2006.

4. Wadden TA. Treatment of obesity by moderate and severe caloric restriction. Results of clinical research trials. Ann Intern Med. 1993;119: 688-693.

5. Rosenbaum M, Leibel RL. The physiology of body weight regulation: relevance to the etiology of obesity in children. Pediatrics. 1998;101: 525-539.

6. Tong PC, Lee ZS, Sea MM, et al. The effect of orlistat-induced weight loss, without concomitant hypocaloric diet, on cardiovascular risk factors and insulin sensitivity in young obese Chinese subjects with or without type 2 diabetes. Arch Intern Med. 2002;162:2428-2435.

7. Wadden TA, Berkowitz RI, Sarwer DB, Prus-Wisniewski R, Steinberg C. Benefits of lifestyle modification in the pharmacologic treatment of obesity: a randomized trial. Arch Intern Med. 2001;161:218-227.

8. Oster G, Thompson D, Edelsberg J, Bird AP, Colditz GA. Lifetime health and economic benefits of weight loss among obese persons. Am J Public Health. 1999;89:1536-1542.

9. Goldstein DJ. Beneficial health effects of modest weight loss. Int $J$ Obes Relat Metab Disord. 1992;16:397-415.

10. Foster-Schubert KE, Cummings DE. Emerging therapeutic strategies for obesity. Endocr Rev. 2006;27:779-793.

11. Halford JCG, Cooper GD, Dovey TM, Ishii Y, Rodgers RJ, Blundell JE. The psychopharmacology of appetite: targets for potential anti-obesity agents. Curr Med Chem. 2003;3:283-310.

12. Bray GA, Greenway FL. Current and potential drugs for treatment of obesity. Endocr Rev. 1999;20:805-875.

13. Carey MC, Hernell O. Digestion and absorption of fat. Semin Gastroint Dis. 1992;3:189-208.

14. Carey MC, Small DM, Bliss CM. Lipid digestion and absorption. Annu Rev Physiol. 1983;45:651-677.

15. Nicolosi RJ, Wilson TA, Lawton C, Handelman GJ. Dietary effects on cardiovascular disease risk factors: beyond saturated fatty acids and cholesterol. J Am Coll Nutr. 2001;20:421S-427S.

16. Mukherjee M. Human digestive and metabolic lipases-a brief review. J Mol Catal, B Enzym. 2003;22:369-376.

17. Birari RB, Bhutani KK. Pancreatic lipase inhibitors from natural sources: unexplored potential. Drug Discov Today. 2007;12:879-989.

18. Hamosh M. Lingual and gastric lipases: their role in fat digestion. Boca Raton, FL: CRC Press; 1990. 
19. Van Gaal L, Mertens I, Ballaux D, Verkade HJ. Modern, new pharmacotherapy for obesity. A gastrointestinal approach. Best Pract Res Clin Gastroenterol. 2004;18:1049-1072.

20. Borgstrom B, Erlanson-Albertsson C. Hydrolysis of milk fat globules by pancreatic lipase. Role of colipase, phospholipase A2, and bile salts. J Clin Invest. 1982;70:30-32.

21. Lowe ME. The triglyceride lipases of the pancreas. J Lipid Res. 2002;43:2007-2016

22. Crenon I, Foglizzo E, Kerfelec B, et al. Pancreatic lipase-related protein type I: a specialized lipase or an inactive enzyme. Protein Eng. 1998;11: 135-142.

23. Lowe ME. Properties and function of pancreatic lipase related protein 2. Biochimie. 2000;82:997-1004.

24. Sias B, Ferrato F, Grandval P, et al. Human pancreatic lipase-related protein 2 is a galactolipase. Biochemistry. 2004;43:10138-10148.

25. Reboul E, Berton A, Moussa M, Kreuzer C, Crenon I, Borel P. Pancreatic lipase and pancreatic lipase-related protein 2, but not pancreatic lipase-related protein 1, hydrolyze retinyl palmitate in physiological conditions. Biochim Biophys Acta. 2006;1761:4-10.

26. Carriere F, Barrowman JA, Verger R, Laugier R. Secretion and contribution to lipolysis of gastric and pancreatic lipases during a test meal in humans. Gastroenterology. 1993;105:876-888.

27. Armand M, Borel P, Dubois C, et al. Characterization of emulsions and lipolysis of dietary lipids in the human stomach. Am J Physiol. 1994;266:G372-G381.

28. Armand M, Borel P, Pasquier B, et al. Physicochemical characteristics of emulsions during fat digestion in human stomach and duodenum. Am J Physiol. 1996;271:G172-G183.

29. Armand M, Pasquier B, Andre M, et al. Digestion and absorption of 2 fat emulsions with different droplet sizes in the human digestive tract. Am J Clin Nutr. 1999;70:1096-1106.

30. Phan CT, Tso P. Intestinal lipid absorption and transport. Front Biosci. 2001;6:D299-D319.

31. Thomson ABR, De Pover A, Keelan M, Jarocka-Cyrta E, Clandinin MT. Inhibition of lipid absorption as an approach to the treatment of obesity. In Rubin B, Dennis EA Editors. Methods in Enzymology. Elsevier: San Diego; 1997:3-41.

32. Shi Y, Burn P. Lipid metabolic enzymes: emerging drug targets for the treatment of obesity. Nat Rev Drug Discov. 2004;3:695-710.

33. van Tilbeurgh H, Sarda L, Verger R, Cambillau C. Structure of the pancreatic lipase-procolipase complex. Nature. 1992;359:159-162.

34. $\mathrm{Mu} \mathrm{H}$, Hoy CE. The digestion of dietary triacylglycerols. Prog Lipid Res. 2004;43:105-133

35. Englyst KN, Englyst HN. Carbohydrate bioavailability. Br J Nutr. 2005;94:1-11.

36. Cummings JH, Macfarlane GT, Englyst HN. Prebiotic digestion and fermentation. Am J Clin Nutr. 2001;73:415S-420S.

37. Grabitske HA, Slavin JL. Gastrointestinal effects of low-digestible carbohydrates. Crit Rev Food Sci Nutr. 2009;49:327-360.

38. Hofbauer KG. Molecular pathways to obesity. Int J Obes Relat Metab Disord. 2002;26 Supp1 2:S18-S27.

39. Weigle DS. Pharmacological therapy of obesity: Past, present, and future. Clin Endocrinol Metab. 2003;88:2462-2469.

40. Lissner L, Heitmann BL. Dietary fat and obesity: evidence from epidemiology. Eur J Clin Nutr. 1995;49:79-90.

41. Klein S. Long-term pharmacotherapy for obesity. Obes Res. 2004;12 Suppl:163S-166S.

42. Aronne LJ. Obesity. Med Clin North Am. 1998;82:161-181.

43. Miled N, Canaan S, Dupuis L, et al. Digestive lipases: from threedimensional structure to physiology. Biochimie. 2000;82:973-986.

44. Ayvazian L, Kerfelec B, Granon S, et al. The lipase C-terminal domain. A novel unusual inhibitor of pancreatic lipase activity. J Biol Chem. 2001;276:14014-14018

45. Sebban-Kreuzer C, Ayvazian L, Juhel C, Salles JP, Chapus C, Kerfelec B. Inhibitory effect of the pancreatic lipase C-terminal domain on intestinal lipolysis in rats fed a high-fat diet: chronic study. Int J Obes Relat Metab Disord. 2003;27:319-325.
46. Yamada Y, Kato T, Ogino H, Ashina S, Kato K. Cetilistat (ATL-962), a novel pancreatic lipase inhibitor, ameliorates body weight gain and improves lipid profiles in rats. Horm Metab Res. 2008;40:539-543.

47. Bryson A, de la Motte S, Dunk C. Reduction of dietary fat absorption by the novel gastrointestinal lipase inhibitor cetilistat in healthy volunteers. Br J Clin Pharmacol. 2009;67:309-315.

48. Kopelman P, Bryson A, Hickling R, et al. Cetilistat (ATL-962), a novel lipase inhibitor: a 12-week randomized, placebo-controlled study of weight reduction in obese patients. Int J Obes (Lond). 2007;31:494-499.

49. Kopelman P, de HGG, Rissanen A, et al. Weight loss, HbA(1c) reduction, and tolerability of cetilistat in a randomized, placebo-controlled phase 2 trial in obese diabetics: comparison with orlistat (Xenical). Obesity (Silver Spring). 2010;18:108-115.

50. Slanc P, Doljak B, Kreft S, Lunder M, Janes D, Strukelj B. Screening of selected food and medicinal plant extracts for pancreatic lipase inhibition. Phytother Res. 2009;23:874-877.

51. Hostettmann K, Marston A. Saponins. Cambridge: Cambridge University Press; 1995:560.

52. Jiang W, Li W, Han L, et al. Biologically active triterpenoid saponins from Acanthopanax senticosus. J Nat Prod. 2006;69:1577-1581.

53. Yoshizumi K, Hirano K, Ando H, et al. Lupane-type saponins from leaves of Acanthopanax sessiliflorus and their inhibitory activity on pancreatic lipase. J Agric Food Chem . 2006;54:335-341.

54. Liu W, Zheng Y, Han L, et al. Saponins (Ginsenosides) from stems and leaves of Panax quinquefolium prevented high-fat diet-induced obesity in mice. Phytomedicine. 2008;15:1140-1145.

55. Fujikawa T, Yamaguchi A, Morita I, Takeda H, Nishibe S. Protective effects of Acanthopanax senticosus Harms from Hokkaido and its components on gastric ulcer in restrained cold water stressed rats. Biol Pharm Bull. 1996;19:1227-1230.

56. Gaffney BT, Hugel HM, Rich PA. Panax ginseng and Eleutherococcus senticosus may exaggerate an already existing biphasic response to stress via inhibition of enzymes which limit the binding of stress hormones to their receptors. Med Hypotheses. 2001;56:567-572.

57. Yi JM, Hong SH, Kim JH, Kim HK, Song HJ, Kim HM. Effect of Acanthopanax senticosus stem on mast cell-dependent anaphylaxis. J Ethnopharmacol. 2002;79:347-352.

58. Jung HJ, Park HJ, Kim RG, et al. In vivo anti-inflammatory and antinociceptive effects of liriodendrin isolated from the stem bark of Acanthopanax senticosus. Planta Med. 2003;69:610-616.

59. Deyama T, Nishibe S, Nakazawa Y. Constituents and pharmacological effects of Eucommia and Siberian ginseng. Acta Pharmacol Sin. 2001;22:1057-1070.

60. Brekhman II, Dardymov IV. New substances of plant origin which increase nonspecific resistance. Annu Rev Pharmacol. 1969;9: 419-430.

61. Li F, Li W, Fu H, Zhang Q, Koike K. Pancreatic lipase-inhibiting triterpenoid saponins from fruits of Acanthopanax senticosus. Chem Pharm Bull (Tokyo). 2007;55:1087-1089.

62. Cha YS, Soh JR, Kim JW. Acanthopanax senticosus extract prepared from cultured cells improves lipid parameters in rats fed with a high fat diet. J Korean Soc Nutraceut Food. 2003;8:40-45.

63. Cha YS, Rhee SJ, Heo YR. Acanthopanax senticosus extract prepared from cultured cells decreases adiposity and obesity indices in C57BL/6J mice fed a high fat diet. J Med Food. 2004;7:422-429.

64. Lee YJ, Chung HY, Kwak HK, Yoon S. The effects of A. senticosus supplementation on serum lipid profiles, biomarkers of oxidative stress, and lymphocyte DNA damage in postmenopausal women. Biochem Biophys Res Commun. 2008;375:44-48.

65. Park SH, Lee SG, Kang SK, Chung SH. Acanthopanax senticosus reverses fatty liver disease and hyperglycemia in ob/ob mice. Arch Pharm Res. 2006;29:768-776.

66. Yoshizumi K, Murota K, Watanabe S, Tomi H, Tsuji T, Terao J. Chiisanoside is not absorbed but inhibits oil absorption in the small intestine of rodents. Biosci Biotechnol Biochem. 2008;72:1126-1129.

67. Qian XZ. Colored Illustrations of Chinese Herbs: Part II. Beijing: People's Health Press; 1996. 
68. Kimura H, Ogawa S, Katsube T, Jisaka M, Yokota K. Antiobese effects of novel saponins from edible seeds of Japanese horse chestnut (Aesculus turbinata BLUME) after treatment with wood ashes. J Agric Food Chem. 2008;56:4783-4788.

69. Hu JN, Zhu XM, Han LK, et al. Anti-obesity effects of escins extracted from the seeds of Aesculus turbinata BLUME (Hippocastanaceae). Chem Pharm Bull (Tokyo). 2008;56:12-16.

70. Kimura H, Ogawa S, Jisaka M, Kimura Y, Katsube T, Yokota K. Identification of novel saponins from edible seeds of Japanese horse chestnut (Aesculus turbinata Blume) after treatment with wooden ashes and their nutraceutical activity. J Pharm Biomed Anal. 2006;41:1657-1665.

71. Yoshikawa M, Sugimoto S, Kato Y, et al. Acylated oleanane-type triterpene saponins with acceleration of gastrointestinal transit and inhibitory effect on pancreatic lipase from flower buds of chinese tea plant (Camellia sinensis). Chem Biodivers. 2009;6:903-915.

72. Kwon CS, Sohn HY, Kim SH, et al. Anti-obesity effect of Dioscorea nipponica Makino with lipase-inhibitory activity in rodents. Biosci Biotechnol Biochem. 2003;67:1451-1456.

73. Han LK, Kimura Y, Kawashima M, et al. Anti-obesity effects in rodents of dietary teasaponin, a lipase inhibitor. Int J Obes. 2001;25:1459-1464.

74. Han LK, Takaku T, Li J, Kimura Y, Okuda H. Anti-obesity action of oolong tea. Int J Obes Relat Metab Disord. 1999;23:98-105.

75. Leonhardt M, Hrupka B, Langhans W. New approaches in the pharmacological treatment of obesity. Eur J Nutr. 1999;38:1-13.

76. Han LK, Zheng YN, Yoshikawa M, Okuda H, Kimura Y. Anti-obesity effects of chikusetsusaponins isolated from Panax japonicus rhizomes. BMC Complement Altern Med. 2005;5:9.

77. Hiroahi I, Kauzuo T, Yohko Y. Saponins from the roots of Platycodon grandiflorum. Part 1: structure of prosapogenins. J Chem Soc Perkin Trans. 1981;1928-1933.

78. Kim KS, Ezaki O, Ikemoto S, Itakura H. Effects of Platycodon grandiflorum feeding on serum and liver lipid concentrations in rats with diet-induced hyperlipidemia. J Nutr Sci Vitaminol (Tokyo). 1995;41: 485-491.

79. Xu BJ, Han LK, Zheng YN, Lee JH, Sung CK. In vitro inhibitory effect of triterpenoidal saponins from Platycodi Radix on pancreatic lipase. Arch Pharm Res. 2005;28:180-185.

80. Han L, Zheng Y, Xu B, Okuda H, Kimura Y. Saponins from Platycodi radix ameliorate high fat diet-induced obesity in mice. J Nutr. 2002; 132:2241-2245.

81. Han LK, Xu BJ, Kimura Y, Zheng Y, Okuda H. Platycodi radix affects lipid metabolism in mice with high fat diet-induced obesity. J Nutr. 2000;130:2760-2764

82. Zhao HL, Kim YS. Determination of the kinetic properties of platycodin $\mathrm{D}$ for the inhibition of pancreatic lipase using a 1,2-diglyceride-based colorimetric assay. Arch Pharm Res. 2004;27:1048-1052.

83. Zhao HL, Sim JS, Ha YW, Kang SS, Kim YS. Antiobese and hypolipidemic effects of platycodin saponins in diet-induced obese rats: evidences for lipase inhibition and calorie intake restriction. Int J Obes (Lond). 2005;29:983-990.

84. Lee EB. Pharmacological activities of crude platycodin. J Pharmaceut Soc Korea. 1975;19:164-176.

85. Chung MS, Kim NC, Long L, et al. Dereplication of saccharide and polyol constituents of candidate sweet-tasting plants: isolation of the sesquiterpene glycoside mukurozioside IIb as a sweet principle of Sapindus rarak. Phytochemical Analysis. 1997;8:49-54.

86. Morikawa T, Xie Y, Asao Y, et al. Oleanane-type triterpene oligoglycosides with pancreatic lipase inhibitory activity from the pericarps of Sapindus rarak. Phytochemistry. 2009;70:1166-1172.

87. Zheng Q, Koike K, Han LK, Okuda H, Nikaido T. New biologically active triterpenoid saponins from Scabiosa tschiliensis. J Nat Prod. 2004;67:604-613.

88. Guo T, Liu Q, Wang P, Zhang L, Zhang W, Li Y. Facile synthesis of three bidesmosidic oleanolic acid saponins with strong inhibitory activity on pancreatic lipase. Carbohydr Res. 2009;344:1167-1174.

89. Arts IC, Hollman PC. Polyphenols and disease risk in epidemiologic studies. Am J Clin Nutr. 2005;81:317S-325S.
90. Griffiths DW. The inhibition of digestive enzymes by polyphenolic compounds. Adv Exp Med Biol. 1986;199:509-516.

91. Horigome T, Kumar R, Okamoto K. Effects of condensed tannins prepared from leaves of fodder plants on digestive enzymes in vitro and in the intestine of rats. Br J Nutr. 1988;60:275-285.

92. Al-Mamary M, Al-Aghbari A, Al-Habori M, Al-Obeidi A. In vivo effects of dietary sorghum tannins on rabbit digestive enzymes and mineral absorption. Nutr Res. 2001;21:1393-1401.

93. Nonaka G, Hsu F, Nishioka I. Structures of dimeric, trimeric, and tetrameric procyanidins from Areca catechu L. J Chem Soc Chem Commun. 1981:781-784.

94. Leontowicz H, Gorinstein S, Lojek A, et al. Comparative content of some bioactive compounds in apples, peaches and pears and their influence on lipids and antioxidant capacity in rats. $J$ Nutr Biochem. 2002;13:603-610.

95. Akiyama H, Sato Y, Watanabe T, et al. Dietary unripe apple polyphenol inhibits the development of food allergies in murine models. FEBS Lett. 2005;579:4485-4491.

96. Gosse F, Guyot S, Roussi S, et al. Chemopreventive properties of apple procyanidins on human colon cancer-derived metastatic SW620 cells and in a rat model of colon carcinogenesis. Carcinogenesis. 2005;26:1291-1295.

97. Sugiyama H, Akazome Y, Shoji T, et al. Oligomeric procyanidins in apple polyphenol are main active components for inhibition of pancreatic lipase and triglyceride absorption. J Agric Food Chem. 2007;55:4604-4609.

98. Yamamoto M, Shimura S, Itoh Y, Ohsaka T, Egawa M, Inoue S. Antiobesity effects of lipase inhibitor CT-II, an extract from edible herbs, Nomame Herba, on rats fed a high-fat diet. Int J Obes Relat Metab Disord. 2000;24:758-764.

99. Ardevol A, Blade C, Salvado MJ, Arola L. Changes in lipolysis and hormone-sensitive lipase expression caused by procyanidins in 3T3-L1 adipocytes. Int J Obes Relat Metab Disord. 2000;24:319-324.

100. de Freitas VA, Glories Y, Laguerre M. Incidence of Molecular Structure in Oxidation of Grape Seed Procyanidins. J Agric Food Chem. 1998;46:376-382.

101. Moreno DA, Ilic N, Poulev A, Brasaemle DL, Fried SK, Raskin I. Inhibitory effects of grape seed extract on lipases. Nutrition. 2003; 19:876-879.

102. Yamakoshi J, Saito S, Kataoka S, Kikuchi M. Safety evaluation of proanthocyanidin-rich extract from grape seeds. Food Chem Toxicol. 2002;40:599-607.

103. Thorsen MA, Hildebrandt KS. Quantitative determination of phenolic diterpenes in rosemary extracts. Aspects of accurate quantification. J Chromatogr A. 2003;995:119-125.

104. Ninomiya K, Matsuda H, Shimoda H, et al. Carnosic acid, a new class of lipid absorption inhibitor from sage. Bioorg Med Chem Lett. 2004;14:1943-1946.

105. Machida K, Oyama K, Ishii M, Kakuda R, Yaoita Y, Kikuchi M. Studies of the constituents of Gardenia species. II. Terpenoids from Gardeniae Fructus. Chem Pharm Bull (Tokyo). 2000;48:746-748.

106. Mathews-Roth MM. Effect of crocetin on experimental skin tumors in hairless mice. Oncology. 1982;39:362-364.

107. Abe K, Sugiura M, Shoyama Y, Saito H. Crocin antagonizes ethanol inhibition of NMDA receptor-mediated responses in rat hippocampal neurons. Brain Res. 1998;787:132-138.

108. Ochiai T, Ohno S, Soeda S, Tanaka H, Shoyama Y, Shimeno H. Crocin prevents the death of rat pheochromyctoma (PC-12) cells by its antioxidant effects stronger than those of alpha-tocopherol. Neurosci Lett. 2004;362:61-64.

109. Lee IA, Lee JH, Baek NI, Kim DH. Antihyperlipidemic effect of crocin isolated from the fructus of Gardenia jasminoides and its metabolite Crocetin. Biol Pharm Bull. 2005;28:2106-2110.

110. Weibel EK, Hadvary P, Hochuli E, Kupfer E, Lengsfeld H. Lipstatin, an inhibitor of pancreatic lipase, produced by Streptomyces toxytricini. I. Producing organism, fermentation, isolation and biological activity. J Antibiot (Tokyo). 1987;40:1081-1085. 
111. Guerciolini R. Mode of action of orlistat. Int J Obes Relat Metab Disord. 1997;21 Suppl 3:S12-S23.

112. Hadvary P, Sidler W, Meister W, Vetter W, Wolfer H. The lipase inhibitor tetrahydrolipstatin binds covalently to the putative active site serine of pancreatic lipase. J Biol Chem. 1991;266:2021-2027.

113. Carriere F, Renou C, Ransac S, et al. Inhibition of gastrointestinal lipolysis by Orlistat during digestion of test meals in healthy volunteers. Am J Physiol Gastrointest Liver Physiol. 2001;281:G16-G28.

114. Sternby B, Hartmann D, Borgstrom B, Nilsson A. Degree of in vivo inhibition of human gastric and pancreatic lipases by Orlistat (Tetrahydrolipstatin, THL) in the stomach and small intestine. Clin Nutr. 2002;21:395-402.

115. Halford JCG. Pharmacotherapy for obesity. Appetite. 2006:6-10.

116. Zhi J, Melia AT, Guerciolini R, et al. Retrospective population-based analysis of the dose-response (fecal fat excretion) relationship of orlistat in normal and obese volunteers. Clin Pharmacol Ther. 1994;56:82-85.

117. Fernandez E, Borgstrom B. Effects of tetrahydrolipstatin, a lipase inhibitor, on absorption of fat from the intestine of the rat. Biochim Biophys Acta. 1989;1001:249-255.

118. Hauptman JB, Jeunet FS, Hartmann D. Initial studies in humans with the novel gastrointestinal lipase inhibitor Ro 18-0647 (tetrahydrolipstatin). Am J Clin Nutr. 1992;55:309S-313S.

119. Hussain Y, Guzelhan C, Odink J, van der Beek EJ, Hartmann D. Comparison of the inhibition of dietary fat absorption by full versus divided doses of orlistat. J Clin Pharmacol. 1994;34:1121-1125.

120. Sjostrom L, Rissanen A, Andersen T, et al. Randomised placebocontrolled trial of orlistat for weight loss and prevention of weight regain in obese patients. European Multicentre Orlistat Study Group. Lancet. 1998;352:167-172.

121. Torgerson JS, Hauptman J, Boldrin MN, Sjostrom L. Xenical in the prevention of diabetes in obese subjects (XENDOS) study: a randomized study of orlistat as an adjunct to lifestyle changes for the prevention of type 2 diabetes in obese patients. Diabetes Care. 2004;27:155-161.

122. Rossner S, Sjostrom L, Noack R, Meinders AE, Noseda G. Weight loss, weight maintenance, and improved cardiovascular risk factors after 2 years treatment with orlistat for obesity. European Orlistat Obesity Study Group. Obes Res. 2000;8:49-61.

123. Scheen AJ, Ernest P. New antiobesity agents in type 2 diabetes: overview of clinical trials with sibutramine and orlistat. Diabetes Metab. 2002;28:437-445.

124. Karhunen L, Franssila-Kallunki A, Rissanen P, et al. Effect of orlistat treatment on body composition and resting energy expenditure during a two-year weight-reduction programme in obese Finns. Int $J$ Obes Relat Metab Disord. 2000;24:1567-1572.

125. Ballinger A, Peikin SR. Orlistat: its current status as an anti-obesity drug. Eur J Pharmacol. 2002;440:109-117.

126. Melia AT, Zhi J, Koss-Twardy SG, et al. The influence of reduced dietary fat absorption induced by orlistat on the pharmacokinetics of digoxin in healthy volunteers. J Clin Pharmacol. 1995;35:840-843.

127. O'Donovan D, Horowitz M, Russo A, et al. Effects of lipase inhibition on gastric emptying of, and on the glycaemic, insulin and cardiovascular responses to, a high-fat/carbohydrate meal in type 2 diabetes. Diabetologia. 2004;47:2208-2214.

128. Filippatos TD, Derdemezis CS, Gazi IF, Nakou ES, Mikhailidis DP, Elisaf MS. Orlistat-associated adverse effects and drug interactions: a critical review. Drug Saf. 2008;31:53-65.

129. Beaver J, Bell JD, Thomas EL, et al. Orlistat $60 \mathrm{mg}$ in conjunction with diet provides significant reduction in visceral adipose tissue. 1st International Congress on Abdominal Obesity, Hong Kong; 2010.

130. Greenway F, Smith SR, Murray K, et al. Orlistat $60 \mathrm{mg}$ demonstrates a significant reduction in visceral adipose tissue at 24 weeks compared with placebo, in 1st International Congress on Abdominal Obesity, Hong Kong; 2010.

131. Mutoh M, Nakada N, Matsukuma S, et al. Panclicins, novel pancreatic lipase inhibitors. I. Taxonomy, fermentation, isolation and biological activity. J Antibiot (Tokyo). 1994;47:1369-1375.
132. Nonaka Y, Ohtaki H, Ohtsuka E, et al. Effects of ebelactone B, a lipase inhibitor, on intestinal fat absorption in the rat. $J$ Enzyme Inhib. 1996;10:57-63.

133. Liu DZ, Wang F, Liao TG, et al. Vibralactone: a lipase inhibitor with an unusual fused beta-lactone produced by cultures of the basidiomycete Boreostereum vibrans. Org Lett. 2006;8:5749-5752.

134. Jain NK, Boivin M, Zinsmeister AR, Brown ML, Malagelada JR, DiMagno EP. Effect of ileal perfusion of carbohydrates and amylase inhibitor on gastrointestinal hormones and emptying. Gastroenterology. 1989;96:377-387.

135. Jain NK, Boivin M, Zinsmeister AR, DiMagno EP. The ileum and carbohydrate-mediated feedback regulation of postprandial pancreaticobiliary secretion in normal humans. Pancreas. 1991;6:495-505.

136. Salvatore T, Giugliano D. Pharmacokinetic-pharmacodynamic relationships of Acarbose. Clin Pharmacokinet. 1996;30:94-106.

137. Hildebrand I, Boehme K, Frank G, Fink H, Berchtold P. The effects of the alpha-glucosidase inhibitor BAY g 5421 (Acarbose) on postprandial blood glucose, serum insulin, and triglyceride levels: dosetime-response relationships in man. Res Exp Med. 1979;175:87-94.

138. Samulitis BK, Goda T, Lee SM, Koldovsky O. Inhibitory mechanism of acarbose and 1-deoxynojirimycin derivatives on carbohydrases in rat small intestine. Drugs Exp Clin Res. 1987;13:517-524.

139. Puls W, Keup U, Krause HP, Thomas G. Pharmacological significance of glucosidase inhibitors (acarbose) Regulators of intestinal absorption in obesity, diabetes and nutrition. in Regulators of intestinal absorption in obesity, diabetes and nutrition. Proceedings of Satellite Symposium n. 7 Third International Congress on Obesity. Siena, Italy: Societa Editrice Universo; 1981.

140. William-Olsson T. alpha-Glucosidase inhibition in obesity. Acta Med Scand Suppl. 1985;706:1-39.

141. Wolever TM, Chiasson JL, Josse RG, et al. Small weight loss on longterm acarbose therapy with no change in dietary pattern or nutrient intake of individuals with non-insulin-dependent diabetes. Int J Obes Relat Metab Disord. 1997;21:756-763.

142. Sonmez AS, Yasar L, Savan K, et al. Comparison of the effects of acarbose and metformin use on ovulation rates in clomiphene citrate-resistant polycystic ovary syndrome. Hum Reprod. 2005;20:175-179.

143. Penna IA, Canella PR, Reis RM, Silva de Sa MF, Ferriani RA. Acarbose in obese patients with polycystic ovarian syndrome: a double-blind, randomized, placebo-controlled study. Hum Reprod. 2005;20:2396-2401.

144. Tugrul S, Kutlu T, Pekin O, Baglam E, Kiyak H, Oral O. Clinical, endocrine, and metabolic effects of acarbose, a alpha-glucosidase inhibitor, in overweight and nonoverweight patients with polycystic ovarian syndrome. Fertil Steril. 2008;90:1144-1148.

145. Asano N, Yamashita T, Yasuda K, et al. Polyhydroxylated alkaloids isolated from mulberry trees (Morusalba L.) and silkworms (Bombyx mori L.). J Agric Food Chem. 2001;49:4208-4213.

146. Kong WH, Oh SH, Ahn YR, Kim KW, Kim JH, Seo SW. Antiobesity effects and improvement of insulin sensitivity by 1-deoxynojirimycin in animal models. J Agric Food Chem. 2008;56:2613-2619.

147. Madar Z, Olefsky J. Effect of the alpha-glucosidase inhibitor Bay-O1248 on the metabolic response of nondiabetic and diabetic rats to a high-carbohydrate diet. Am J Clin Nutr. 1986;44:206-211.

148. Cauderay M, Tappy L, Temler E, Jequier E, Hillebrand I, Felber JP. Effect of alpha-glycohydrolase inhibitors (Bay m1099 and Bay o1248) on sucrose metabolism in normal men. Metabolism. 1986;35:472-477.

149. Hillebrand I, Boehme K, Graefe KH, Wehling K. The effect of new alpha-glucosidase inhibitors (BAY m 1099 and BAY o 1248) on meal-stimulated increases in glucose and insulin levels in man. Klin Wochenschr. 1986;64:393-396.

150. Hansawasdi C, Kawabata J, KasaiT.Alpha-amylase inhibitors from roselle (Hibiscus sabdariffa Linn.) tea. Biosci Biotechnol Biochem. 2000;64: 1041-1043.

151. Matsui T, Yoshimoto C, Osajima K, Oki T, Osajima Y. In vitro survey of alpha-glucosidase inhibitory food components. Biosci Biotechnol Biochem. 1996;60:2019-2022. 
152. Kobayashi Y, Suzuki M, Satsu H, et al. Green tea polyphenols inhibit the sodium-dependent glucose transporter of intestinal epithelial cells by a competitive mechanism. J Agric Food Chem. 2000;48:5618-5623.

153. Zhong L, Furne JK, Levitt MD. An extract of black, green, and mulberry teas causes malabsorption of carbohydrate but not of triacylglycerol in healthy volunteers. Am J Clin Nutr. 2006;84:551-555.

154. Marshall JJ, Lauda CM. Purification and properties of phaseolamin, an inhibitor of alpha-amylase, from the kidney bean, Phaseolus vulgaris. J Biol Chem. 1975;250:8030-8037.

155. Hollenbeck CB, Coulston AM, Quan R, et al. Effects of a commercial starch blocker preparation on carbohydrate digestion and absorption: in vivo and in vitro studies. Am J Clin Nutr. 1983;38:498-503.

156. Kotaru M, Iwami K, Yeh HY, Ibuki F. In vivo action of alpha-amylase inhibitor from cranberry bean (Phaseolus vulgaris) in rat small intestine. J Nutr Sci Vitaminol (Tokyo). 1989;35:579-588.

157. Tormo MA, Gil-Exojo I, Romero de Tejada A, Campillo JE. Hypoglycaemic and anorexigenic activities of an alpha-amylase inhibitor from white kidney beans (Phaseolus vulgaris) in Wistar rats. BrJ Nutr. 2004;92:785-790.

158. Tormo MA, Gil-Exojo I, Romero de Tejada A, Campillo JE. White bean amylase inhibitor administered orally reduces glycaemia in type 2 diabetic rats. Br J Nutr. 2006;96:539-544.

159. Jaffe WG, Lette CL. Heat-labile growth-inhibiting factors in beans (Phaseolus vulgaris). J Nutr. 1968;94:203-210.

160. Pusztai A, Grant G, Duguid T, et al. Inhibition of starch digestion by alpha-amylase inhibitor reduces the efficiency of utilization of dietary proteins and lipids and retards the growth of rats. J Nutr. 1995;125: 1554-1562.

161. Fantini N, Cabras C, Lobina C, et al. Reducing Effect of a Phaseolus vulgaris dry extract on food intake, body weight, and glycemia in rats. J Agric Food Chem. 2009;14:9316-9323.

162. Maranesi M, Carenini G, Gentili P. Nutritional studies on anti alphaamylase: I) Influence on the growth rate, blood picture and biochemistry and histological parameters in rats. Acta Vitaminol Enzymol. 1984;6:259-269.

163. Bo-Linn GW, Santa Ana CA, Morawski SG, Fordtran JS. Starch blockers-their effect on calorie absorption from a high-starch meal. N Engl J Med. 1982;307:1413-1416.

164. Carlson GL, Li BU, Bass P, Olsen WA. A bean alpha-amylase inhibitor formulation (starch blocker) is ineffective in man. Science. 1983;219: 393-395.

165. Udani J, Hardy M, Madsen DC. Blocking carbohydrate absorption and weight loss: a clinical trial using Phase 2 brand proprietary fractionated white bean extract. Altern Med Rev. 2004;9:63-69.

166. Layer P, Carlson GL, DiMagno EP. Partially purified white bean amylase inhibitor reduces starch digestion in vitro and inactivates intraduodenal amylase in humans. Gastroenterology. 1985;88:1895-1902.

167. Vinson J. Investigation on the efficacy of Phaseolamin 2250, a purified bean extract from Pharmachem Laboratories. University of Scranton; 2001.

168. Layer P, Rizza RA, Zinsmeister AR, Carlson GL, DiMagno EP. Effect of a purified amylase inhibitor on carbohydrate tolerance in normal subjects and patients with diabetes mellitus. Mayo Clin Proc. 1986;61:442-447.

169. Vinson JA, Al Kharrat H, Shuta D. Investigation of an Amylase Inhibitor on Human Glucose Absorption after Starch Consumption. The Open Nutraceuticals Journal. 2009;2:88-91.

170. Meiss DE, Ballerini R. Effectiveness of Phase $2^{\mathrm{TM}}$, a natural alphaamylase inhibitor, for weight loss: a randomized double-blind, placebo-controlled study. Scripps Clinic Natural Supplements in Evidence-Based Practice Conference; 2003.

171. Celleno L, Tolaini MV, D’Amore A, Perricone NV, Preuss HG. A dietary supplement containing standardized Phaseolus vulgaris extract influences body composition of overweight men and women. Int J Med Sci. 2007;4:45-52.
172. Udani J, Singh BB. Blocking carbohydrate absorption and weight loss: a clinical trial using a proprietary fractionated white bean extract. Altern Ther Health Med. 2007;13:32-37.

173. Broadhurst CL, Polansky MM, Anderson RA. Insulin-like biological activity of culinary and medicinal plant aqueous extracts in vitro. J Agric Food Chem. 2000;48:849-852.

174. Jayaprakasam B, Vareed SK, Olson LK, Nair MG. Insulin secretion by bioactive anthocyanins and anthocyanidins present in fruits. J Agric Food Chem. 2005;53:28-31.

175. McDougall GJ, Stewart D. The inhibitory effects of berry polyphenols on digestive enzymes. Biofactors. 2005;23:189-195.

176. Maatta-Riihinen KR, Kamal-Eldin A, Mattila PH, Gonzalez-Paramas AM, Torronen AR. Distribution and contents of phenolic compounds in eighteen Scandinavian berry species. J Agric Food Chem. 2004;52: 4477-4486.

177. Hsu TF, Kusumoto A, Abe K, et al. Polyphenol-enriched oolong tea increases fecal lipid excretion. Eur J Clin Nutr. 2006;60:1330-1336.

178. Tsuda T. Regulation of adipocyte function by anthocyanins; possibility of preventing the metabolic syndrome. JAgric Food Chem. 2008;56: 642-646.

179. Sakurai T, Nishimura T, Otake N, et al. Assamicin I and II, novel triterpenoid saponins with insulin-like activity from Aesculus assamica Griff. Bioorg Med Chem Lett. 2002;12:807-810.

180. Kurihara H, Asami S, Shibata H, Fukami H, Tanaka T. Hypolipemic effect of Cyclocarya paliurus (Batal) Iljinskaja in lipid-loaded mice. Biol Pharm Bull. 2003;26:383-385.

181. Kurihara H, Kusumoto A, Toyoda Y, et al. Hypoglycemic action of Cyclocarya paliurus (Batal.) Iljinskaja in normal and diabetic mice. Biosci Biotechnol Biochem. 2003;67:877-880.

182. Balentine DA, Wiseman SA, Bouwens LC. The chemistry of tea flavonoids. Crit Rev Food Sci Nutr. 1997;37:693-704.

183. Wolfram S, Wang Y, Thielecke F. Anti-obesity effects of green tea: from bedside to bench. Mol Nutr Food Res. 2006;50:176-187.

184. Thielecke F, Boschmann M. The potential role of green tea catechins in the prevention of the metabolic syndrome - a review. Phytochemistry. 2009;70:11-24.

185. Sano M, Tabata M, Suzuki M, Degawa M, Miyase T, Maeda-Yamamoto M. Simultaneous determination of twelve tea catechins by highperformance liquid chromatography with electrochemical detection. Analyst. 2001;126:816-820.

186. Mandel SA, Amit T, Weinreb O, Reznichenko L, Youdim MB. Simultaneous manipulation of multiple brain targets by green tea catechins: a potential neuroprotective strategy for Alzheimer and Parkinson diseases. CNS Neurosci Ther. 2008;14:352-365.

187. Wolfram S, Raederstorff D, Wang Y, Teixeira SR, Elste V, Weber P. TEAVIGO (epigallocatechin gallate) supplementation prevents obesity in rodents by reducing adipose tissue mass. Ann Nutr Metab. 2005;49:54-63.

188. Furuyashiki T, Nagayasu H, Aoki Y, et al. Tea catechin suppresses adipocyte differentiation accompanied by down-regulation of PPARgamma2 and C/EBPalpha in 3T3-L1 cells. Biosci Biotechnol Biochem. 2004;68:2353-2359.

189. Hung PF, Wu BT, Chen HC, et al. Antimitogenic effect of green tea (-)-epigallocatechin gallate on 3T3-L1 preadipocytes depends on the ERK and Cdk2 pathways. Am J Physiol Cell Physiol. 2005; 288:C1094-C1108.

190. Shimizu M, Kobayashi Y, Suzuki M, Satsu H, Miyamoto Y. Regulation of intestinal glucose transport by tea catechins. Biofactors. 2000;13: 61-65.

191. Matsumoto N, Ishigaki F, Ishigaki A, Iwashina H, Hara Y. Reduction of blood glucose levels by tea catechin. Biosci Biotechnol Biochem. 1993;57:525-527.

192. Juhel C, Armand M, Pafumi Y, Rosier C, Vandermander J, Lairon D. Green tea extract (AR25) inhibits lipolysis of triglycerides in gastric and duodenal medium in vitro. J Nutr Biochem. 2000;11:45-51. 
193. Juskiewicz J, Zdunczyk Z, Jurgonski A, Brzuzan L, Godycka-Klos I, Zary-Sikorska E. Extract of green tea leaves partially attenuates streptozotocin-induced changes in antioxidant status and gastrointestinal functioning in rats. Nutr Res. 2008;28:343-349.

194. Sogawa M, Seura T, Kohno S, et al. Awa (Tokushima) lactate-fermented tea as well as green tea enhance the effect of diet restriction on obesity in rats. $J$ Med Invest. 2009;56:42-48.

195. Chantre P, Lairon D. Recent findings of green tea extract AR25 (Exolise) and its activity for the treatment of obesity. Phytomedicine. 2002;9:3-8

196. Mukherjee PK, Saha K, Das J, Pal M, Saha BP. Studies on the antiinflammatory activity of rhizomes of Nelumbo nucifera. Planta Med. 1997;63:367-369.

197. Sinha S, Mukherjee PK, Mukherjee K, Pal M, Mandal SC, Saha BP. Evaluation of antipyretic potential of Nelumbo nucifera stalk extract. Phytother Res. 2000;14:272-274.

198. Jung HA, Kim JE, Chung HY, Choi JS. Antioxidant principles of Nelumbo nucifera stamens. Arch Pharm Res. 2003;26:279-285.

199. Ono Y, Hattori E, Fukaya Y, Imai S, Ohizumi Y. Anti-obesity effect of Nelumbo nucifera leaves extract in mice and rats. J Ethnopharmacol. 2006;106:238-244.

200. Mukherjee PK, Saha K, Pal M, Saha BP. Effect of Nelumbo nucifera rhizome extract on blood sugar level in rats. J Ethnopharmacol. 1997;58:207-213.

201. Muramatsu K, Fukuyo M, Hara Y. Effect of green tea catechins on plasma cholesterol level in cholesterol-fed rats. J Nutr Sci Vitaminol (Tokyo). 1986;32:613-622.

202. Ikeda I, Imasato Y, Sasaki E, et al. Tea catechins decrease micellar solubility and intestinal absorption of cholesterol in rats. Biochim Biophys Acta. 1992;1127:141-146.

203. Nakai M, Fukui Y, Asami S, et al. Inhibitory effects of oolong tea polyphenols on pancreatic lipase in vitro. J Agric Food Chem. 2005; 53:4593-4598

204. Nagao T, Komine Y, Soga S, et al. Ingestion of a tea rich in catechins leads to a reduction in body fat and malondialdehyde-modified LDL in men. Am J Clin Nutr. 2005;81:122-129.
205. Irshad M, Sharma CB. Purification and properties of an alpha-amylase protein-inhibitor from Arachis hypogaea seeds. Biochim Biophys Acta. 1981;659:326-333.

206. Hochstrasser K, Feuth H, Werle E. Isolierung und charakterisierung eines lipasehemmstoffes aus lipiden von Arachis hypogaea. HoppeSeyler's Zeitschrift fur Physiologische Chemie. 1972;353:855-860.

207. Moreno DA, Ilic N, Poulev A, Raskin I. Effects of Arachis hypogaea nutshell extract on lipid metabolic enzymes and obesity parameters. Life Sci. 2006;78:2797-2803.

208. Yoshikawa M, Murakami T, Shimada H, et al. Salacinol, potent antidiabetic principle with unique thiosugar sulfonium sulfate structure from the Ayurvedic traditional medicine Salacia reticulata in Sri Lanka and India. Tetrahedron Lett. 1997:38:8367-8370.

209. Yoshikawa M, Murakami T, Yashiro K, Matsuda H. Kotalanol, a potent alpha-glucosidase inhibitor with thiosugar sulfonium sulfate structure, from antidiabetic ayurvedic medicine Salacia reticulata. Chem Pharm Bull (Tokyo). 1998;46:1339-1340.

210. Yoshikawa M, Shimoda H, Nishida N, Takada M, Matsuda H. Salacia reticulata and its polyphenolic constituents with lipase inhibitory and lipolytic activities have mild antiobesity effects in rats. $J$ Nutr. 2002;132:1819-1824.

211. Han LK, Sumiyoshi M, Zhang J, et al. Anti-obesity action of Salix matsudana leaves (Part 1). Anti-obesity action by polyphenols of Salix matsudana in high fat-diet treated rodent animals. Phytother Res. 2003;17:1188-1194.

212. Han LK, Sumiyoshi M, Zheng YN, Okuda H, Kimura Y. Anti-obesity action of Salix matsudana leaves (Part 2). Isolation of anti-obesity effectors from polyphenol fractions of Salix matsudana. Phytother Res. 2003;17:1195-1198.

213. Han L, Nose R, Li W, et al. Reduction of fat storage in mice fed a high-fat diet long term by treatment with saponins prepared from Kochia scoparia fruit. Phytother Res. 2006;20:877-882.

\section{Publish your work in this journal}

Diabetes, Metabolic Syndrome and Obesity: Targets and Therapy is an international, peer-reviewed open-access journal committed to the rapid publication of the latest laboratory and clinical findings in the fields of diabetes, metabolic syndrome and obesity research. Original research, review, case reports, hypothesis formation, expert opinion and commentaries are all considered for publication. The manuscript management system is completely online and includes a very quick and fair peer-review system, which is all easy to use. Visit http://www.dovepress.com/testimonials.php to read real quotes from published authors. 